\title{
The stimuli-specific role of vasopressin in the hypothalamus-pituitary- adrenal axis response to stress
}

\author{
Dóra Zelena, Ágnes Domokos, Subodh Kumar Jain ${ }^{1}$, Ryan Jankord ${ }^{2}$ and Ludmila Filaretova ${ }^{3}$ \\ Institute of Experimental Medicine, Hungarian Academy of Science, PO Box 67, H-1450 Budapest, Hungary \\ ${ }^{1}$ Department of Zoology and Biotechnology, Dr Harisingh Gour University, Sagar 470003 MP, India \\ ${ }^{2}$ Department of Pyschiatry, University of Cincinnati, Cincinnati, Ohio 45237, USA \\ ${ }^{3}$ Pavlov Institute of Physiology, Russian Academy of Sciences, St Petersburg 199034, Russia \\ (Correspondence should be addressed to D Zelena; Email: zelena@koki.hu)
}

\begin{abstract}
Adaptation to a constantly changing environment is fundamental to every living organism. The hypothalamicpituitary-adrenocortical (HPA) axis is a key component of the adaptation process. The present study tests the hypothesis that vasopressin (AVP) is required for the HPA response to acute stimuli. To accomplish this, naturally AVP-deficient Brattleboro rats were exposed to a wide range of stimuli and their HPA response was compared with heterozygous littermattes. The circadian rhythmicity of plasma ACTH and corticosterone was not different between the two genotypes. The ACTH and corticosterone response to volume load, restraint or aggressive attack were decreased in AVP-deficient rats. The stress-induced increase in ACTH, but not corticosterone, was significantly impaired in AVPdeficient animals after novelty, elevated plus-maze, forced swim, hypoglycaemia, ulcerogenic cold immobilisation,
\end{abstract}

lipopolysaccharide, hypertonic saline and egg white injection. The HPA response to social avoidance, ether inhalation and footshock was not different between the genotypes. In vitro, the hypophysis of AVP-deficient animals showed a reduction in stimulated ACTH production and their adrenal glands were hyporeactive to ACTH. A dissociation between the $\mathrm{ACTH}$ and corticosterone response was observed in several experiments and could not be explained by an earlier ACTH peak or enhanced adrenal sensitivity, suggesting the existence of paraadenohypophyseal neuroendocrine regulators. Loss of AVP affected the HPA response to a wide variety of stressors. Interestingly, the contribution of AVP to the HPA response was not specific for, nor limited to, a known stressor category. Thus, there is a context-specific requirement for AVP in stress-induced activation of the HPA axis.

Journal of Endocrinology (2009) 202, 263-278

\section{Introduction}

Maintaining homeostasis in a constantly changing environment is a fundamental process of life. Hans Selye, the father of the stress concept, defined the hypothalamic-pituitaryadrenocortical (HPA) axis as the major component required for adaptation (Selye 1937). At the time of his discovery, the central regulating molecules of the HPA axis were not established. Following its identification in 1954, arginine vasopressin (AVP) was considered as the principal regulator of ACTH release. The subsequent elucidation of the structure of corticotrophin-releasing hormone $(\mathrm{CRH})$ and the domination of the 'one neuron - one transmitter' principle led to the replacement of AVP with $\mathrm{CRH}$ as the principle regulator of the HPA axis (Scott \& Dinan 2002). Currently, it is thought that the effects of AVP in HPA regulation are restricted to potentiating the stimulatory effects of $\mathrm{CRH}$ at both the pituitary and hypothalamic levels (Buckingham 1981, Ono et al. 1985, Lightman \& Young 1988).
The role of AVP in HPA axis regulation is thought to become more important during chronic stress (Dallman 1993, Aguilera 1994, Ma \& Lightman 1998, Lightman et al. 2002). However, our data has shown that the lack of AVP does not affect the development of chronic hyperactivity of the HPA axis (Zelena et al. 2004, 2006a, Domokos et al. 2008). Furthermore, we found that AVP plays a prominent role in acute hormone changes, for e.g. morphine treatment and withdrawal-induced changes, suggesting that the critical role of AVP in HPA axis regulation may be during exposure to acute stimuli.

There is a wide range of studies on the role of AVP in HPA axis regulation during acute stimuli and during resting conditions. Immunoneutralisation studies revealed a role of AVP in restraint-, formalin- (Tilders et al. 1985) and ether stress- (Ono et al. 1985) induced ACTH elevations; although no role for AVP was found in basal ACTH regulation. Knocking out the $\mathrm{V} 1 \mathrm{~b}$ receptor, the main target of the vasopressinergic HPA axis regulation at the pituitary level, 
resulted either in reduced (Tanoue et al. 2004) or normal (Lolait et al. 2007a) resting ACTH and corticosterone levels. Restraint- $(30 \mathrm{~min}$ ) or aggressive contact-induced release of ACTH and corticosterone was also similar in wild type and V1bR knockout (KO) mice, but the hypoglycaemia-, lipopolysaccharide (LPS)-, forced swim- and ethanolintoxication-induced elevations were significantly diminished (Tanoue et al. 2004, Lolait et al. 2007a,b, Stewart et al. 2008). A selective, non-peptide V1b receptor antagonist (SSR149415) was able to diminish the restraint-induced ACTH increased by $50 \%$ (Serradeil-Le Gal et al. 2002) and inhibited the response to ether exposure but failed to inhibit the HPA axis response to forced swimming (Ramos et al. 2006). Another V1b receptor antagonist (Org) diminished the restraint- and LPS-induced ACTH release without affecting the resting levels and stressinduced corticosterone responses (Spiga et al. 2009).

Brattleboro rats, an AVP-deficient animal model, have been used to test the contribution of AVP to the HPA axis regulation (Valtin \& Schroeder 1964, Lolait et al. 1986). In general, resting pituitary ACTH concentration of homozygous Brattleboro rats appears to be normal, although there are reports of impaired basal ACTH and corticosterone plasma levels (Brudieux et al. 1986, Eckland et al. 1988, Burgess \& Balment 1992). In regards to the acute HPA response to stress, previous studies have shown normal stress responses (Zelena et al. 2003b, 2004, Mlynarik et al. 2007, Domokos et al. 2008) while other studies have shown decreased responses in the Brattleboro rat (Kjaer et al. 1993, Honda et al. 1994).

It is difficult to compare and draw overall conclusions from all these studies as the experimental and breeding conditions varied and there was not even a uniform choice for the proper control to use in studies with Brattleboro rats (Bohus \& de Wied 1998, Zelena et al. 2003b). Thus, it is not clear whether the intensity and/or the nature of the stress or the experimental approaches/conditions are responsible for the differences observed. Therefore, to test the hypothesis that AVP augments the ACTH response to stress in a contextspecific manner; this study was designed to test the Brattleboro rats in a variety of stress conditions with results being compared with the appropriate control (i.e. heterozygous littermates). We used a wide range of stimuli to find out if the intensity and/or nature of the stressors influence the participation of AVP in HPA axis activation. In addition, the responsiveness of the pituitary and adrenals to $\mathrm{CRH}$ and ACTH respectively, were tested in vitro.

\section{Materials and Methods}

\section{Animals}

Adult, male Brattleboro rats ( 330 g, 10-12 weeks old) were maintained in our institute in a colony started from breeder rats from Harlan, Indianapolis, IN, USA. Rats were kept in controlled environment $\left(23 \pm 1{ }^{\circ} \mathrm{C}, 50-70 \%\right.$ humidity, $12 \mathrm{~h}$ light starting at $0700 \mathrm{~h}$ ) and given commercial rat chow (Charles River, Budapest, Hungary) and tap water ad libitum. We standardised the colony using pair-housed $\mathrm{di} /+$ female and di/di male breeders rats (Zelena et al. 2003b). We compared the AVP deficient homozygous (di/di) rats with diabetes insipidus to heterozygous $(\mathrm{di} /+)$ control rats from the same litters. Although the di/ + rats have only one functional allele their neurohypophysis contains large amounts of AVP and they do not show any signs of diabetes insipidus. Rats were tested for water consumption at the age of 6 weeks to define the diabetes insipidus phenotype and then kept two per cage until the experiment. Age-matched animals were used. To avoid the disturbance of presently untreated animals all experiments were performed on single-housed animals (max. 3-4 day isolation). Separate sets of animals were used for each stress study and all experiments were done between 0800 and 1200. The experiments were performed in accordance with regulations set by the European Communities Council Directive of 24 November 1986 (86/609/EEC) and were approved by our Institutional Animal Care and Use Committee.

Special controls In some cases, an additional control group was also involved. To ensure that the heterozygous animals behave similarly to a wild type, we used Wistar controls (Charles River) in one experiment (ulcerogenic stimulus). Moreover, by cross-mating we have derived a $+/+$ line from our original colony being in close relationship with each other (heterozygous breeding mothers are the daughters of the $+/+$ mothers) and in one experiment (hypoglycaemia) we also used a $+/+$ group as a control. To exclude the influence of peripheral AVP deficiency in one experiment (forced swim), an Alzet osmotic minipump ( $1 \mathrm{ml} / \mathrm{h}, 14$ days) was implanted under the skin filled with $200 \mathrm{ml}$ of $1 \mathrm{mg} / \mathrm{ml}$ desmopressine (DDAVP, V2 receptor agonist; Ferring Lieciva) under ether anaesthesia (Zelena et al. 2006b).

\section{In situ hybridisation}

The animals were decapitated under basal conditions and the brain and hypophysis were rapidly removed, frozen on dry ice and stored at $-70{ }^{\circ} \mathrm{C}$ until measurement. Brain sections of $16 \mu \mathrm{m}$ were cut on a cryostat and hybridised as previously described (Zelena et al. 2006a). Briefly, Crh mRNA and Pomc (ACTH precursor) mRNA levels were quantified by means of ${ }^{35}$ S-UTP containing riboprobes complementary to the exonic sequences of the gene (the Crh probe was obtained from Dr D Richter, University of Hamburg, Germany, while the plasmid containing the Pomc template was a generous gift from Dr J Eberwine, University of Pennsylvania). After hybridisation, slides were exposed to imaging plates (Fujifilm, BAS-IP, MS 2340) for $72(\mathrm{CRH})$ or $16 \mathrm{~h}$ (POMC) and the plates were scanned by a fluorescent image analyser (FLA 3000, Fujifilm, scanning resolution of $50 \mu \mathrm{m})$. Radiograms were evaluated by the ImageJ program (http://rsbweb.nih.gov/ij/). The integrated densities for the nucleus paraventricularis hypothalami (PVN) (Crh mRNA; 
Barna et al. 2003, Zelena et al. 2003a) or the average densities for the hypophysis (Pomc mRNA; Zelena et al. 2007) were calculated. The data were summarised from three hybridisation series expressing the levels of AVP-deficient animals as a percentage of their heterozygous littermate controls.

\section{Blood sampling}

Depending on the experimental procedure, three different blood sampling techniques, as described below, were used in this study. Blood samples were collected on ice and $\mathrm{K}_{2}$-EDTA was used as anticoagulant. After centrifugation, plasma was stored at $-20{ }^{\circ} \mathrm{C}$ until hormone measurement.

I. In most cases, the time course of the hormones was established by repeated blood sampling through i.v. catheter implanted into the right jugular vein under anaesthesia i.p. injection of ketamine $(50 \mathrm{mg} / \mathrm{kg}$, SelBruHa Allatgyogyaszati Kft, Budapest, Hungary) xylazine (20 mg/kg, Spofa, Prague, Czech Republic) promethazinium chloratum $(0.2 \mathrm{ml} / \mathrm{kg}$, EGIS, Budapset, Hungary) in physiological saline (Zelena et al. 2005). After surgery, the animals were housed singly and allowed to recover for 2 days. On the day of the experiment, the animals were connected to a long polyethylene cannula and after taking the first sample the rats were stressed and blood samples $(0.4 \mathrm{ml} / \mathrm{sample})$ were taken at respective time points without additional animal handling. Collected blood was replaced by physiological saline to avoid the additional stimulus of volume loss. The animals were killed by high-dose pentobarbital administered i.v. after the conclusion of the experiment.

II. When mild stressors were used, blood was collected at a single time point at the expected peak of ACTH. In behavioural tests (elevated plus-maze (EPM), social avoidance), tail sampling was used at the end of the test. Animals were placed in a restraint tube and their tail was cut with a surgical knife and blood collected into Eppendorf tubes within $0.5 \mathrm{~min}$ of touching their cage (Mikics et al. 2007). The animals were killed by a high dose i.p. penthobarbital injection.

III. In other tests (for e.g. novelty, lipopolisaccharide injection), rapid decapitation was performed within $0.5 \mathrm{~min}$ of removing animal from cage and trunk blood was collected. For the ether stimuli, we were able to choose a single time point based upon previous observations from our laboratory. The time point for blood collection during hypoglycaemia was chosen based upon the work of Lolait et al. (2007a) who suggested that there is a role of AVP in hypoglycaemia-induced HPA axis activation.

Daily rhythm A separate group of animals was placed in a room with reversed light cycle (lights off at $1000 \mathrm{~h}$ ) and habituated for at least 2 weeks. Two days after i.v. cannula implantation serial blood samples were taken every $2 \mathrm{~h}$ six times a day from both normal (for blood sampling 0-12 h) and reversed light cycle (for blood sampling 12-24 h) animals. The procedure was repeated on the next day with $12 \mathrm{~h}$ rest between. The data from the two series were fitted in time (the beginning of the light phase, referred to as Zeitgeber time 0) and were presented as a single line.

\section{Type of stressors (same order as in results)}

Novelty Rats were placed into an open plastic cage (40 $\times 36 \times 20 \mathrm{~cm})$ without bedding material for $10 \mathrm{~min}$. This cage is bigger than the home-cage $(30 \times 36 \times 20 \mathrm{~cm})$ and was previously defecated by another rat to induce more severe anxiety. Non-handled controls and stressed animals were decapitated at the end of 10 min novelty exposure.

Social avoidance Anxiety was provoked by a two-chamber method developed in our institute (Haller et al. 2003). The apparatus consisted of two connected chambers, one of which contained an unfamiliar Wistar male confined in a subchamber with a perforated Plexiglas wall. The subjects were placed in the empty chamber and, after $3 \mathrm{~min}$ of habituation, were allowed to explore the apparatus for $5 \mathrm{~min}$. Upon completion, blood was collected by tail cuts.

Elevated plus-maze Animals were placed to an EPM (arm length, $50 \mathrm{~cm}$; width, $20 \mathrm{~cm}$; platform height, $70 \mathrm{~cm} ; 440$ lux), a common procedure used for anxiety measurements (Zelena et al. 1999a). Test duration was $5 \mathrm{~min}$ and blood was taken at the end via tail cuts (Mikics et al. 2007).

LPS challenge Based on previous experiments (Foldes et al. 2000) and our preliminary data Escherichia coli LPS, serotype 0111:B4 (Sigma Chemical Co.), was used at a dose $(300 \mu \mathrm{g} / \mathrm{kg})$ that submaximally activates the HPA axis. LPS was dissolved in sterile, pyrogen-free saline and injected i.p. and rats were decapitated $1 \mathrm{~h}$ after injection.

Ether inhalation The animals were put in a glass jar filled with ether vapour for $1 \mathrm{~min}$, and then they were kept anaesthetised for another $2 \mathrm{~min}$ with an ether-soaked nose cone and returned to their home cage. Animals were rapidly decapitated $10 \mathrm{~min}$ after the beginning of the stress (see e.g. (Zelena et al. 1999b)).

Hypertonic saline-volume load $1.5 \mathrm{~mol} / 1 \mathrm{NaCl}$ $(1.5 \mathrm{ml} / 100 \mathrm{~g})$ was injected i.p. and blood samples collected before ( $0 \mathrm{~min})$ and at 5, 15, 30,60 and $120 \mathrm{~min}$ after injection (Ma \& Aguilera 1999). This stress is a combination of osmotic and volume stimulus and pain. Control rats received an equivolume injection of $0 \cdot 15 \mathrm{~mol} / 1 \mathrm{NaCl}$ (physiological saline; $\sim 4.5 \mathrm{ml} / \mathrm{rat})$.

Anaphylactoid reaction Fresh, filtered egg white $(500 \mathrm{ml} / 1$ solution in sterile saline) was slowly injected through the jugular catheter in a dose of $1 \mathrm{ml}$ per $\mathrm{kg}$ 
(Foldes et al. 2000). Blood samples were taken at 0, 5, 15, 30, 60, 90 and $120 \mathrm{~min}$ after injection.

Footshock-footshock box novelty Rats were exposed to repeated electrical footshocks (10-ms pulses of $0.8 \mathrm{~mA}$ at $50 \mathrm{~Hz}$ for $1 \mathrm{~s}$, repeated every $30 \mathrm{~s}$ for $5 \mathrm{~min}$ through a grid floor) as previously described (Zelena et al. 1999c). Control rats were transferred to the same box without electrical impulses. Blood samples were collected from the jugular vein at 0 (before stress), 5, 15, 30, 60, 90 and $120 \mathrm{~min}$.

Restraint A pre-stress blood sample was collected ( $0 \mathrm{~min})$, then the animals were subjected to restraint stress in a polyethylene tube as previously described (Zelena et al. 2003a). Stressor duration was $1 \mathrm{~h}$ and blood samples were collected before (at $0 \mathrm{~min}$ ), during (at 5, 15, 30, 45, 60) and after (at $120 \mathrm{~min}$ ) restraint stress.

Social defeat The test rats were placed into the home cage of a bigger Brattleboro couple (without pups) and left there for $10 \mathrm{~min}$. The test animals lost the confrontation but were not injured. Blood samples were taken before $(0 \mathrm{~min})$ and after stress exposure $(15,30,60,90$ and $120 \mathrm{~min}$ after stressor initiation).

Ulcerogenic cold-immobilisation Cannulated rats were placed into a cold room $\left(4{ }^{\circ} \mathrm{C}\right)$ and immobilised (Kvetnansky \& Mikulaj 1970). Serial blood samples were taken before $(0 \mathrm{~min})$ and during $(30,60,120,180$ and $240 \mathrm{~min}$ ) the stress. The appearance of gastric erosion was visualised by opening the stomach at the end of the $4 \mathrm{~h}$ examination period (Filaretova et al. 1998). For this experiment, a Wistar control group was also used to confirm stressor efficacy to induce ulcers.

Hypoglycaemia After $18 \mathrm{~h}$ fasting, hypoglycaemia was induced by i.p. actrapid injection (3NE/2 ml per kg; Novo Nordisc, Bagsvaerd, Denmark) and the animals were decapitated $1 \mathrm{~h}$ later (Lolait et al. 2007a). Blood glucose levels were measured by a commercially available analyser (D-Cont Personal, 77 Elektronika Kft, Budapest, Hungary). For this experiment, $\mathrm{a}+/+$ control group was also used for comparison with the heterozygous animals.

Forced swim Serial blood samples were taken before $(0 \mathrm{~min})$, during $(5 \mathrm{~min})$ and after $(15,30,60$ and $90 \mathrm{~min})$ a $10 \mathrm{~min}$ forced swim period conducted in a glass cylinder (diameter: $30 \mathrm{~cm}$; height: $50 \mathrm{~cm}$ ) filled with tap water $\left(24^{\circ} \mathrm{C} \pm 1{ }^{\circ} \mathrm{C}\right)$ to a height of $35 \mathrm{~cm}$ (Porsolt et al. 1978). After swimming, the animals were removed from the tank, carefully dried with paper towels and returned to their home cages. An additional control group (DDAVP treatment) was used in this experiment to exclude the influence of peripheral AVP deficiency. Ten days before blood sampling, half of the di/di rats were implanted with osmotic minipump (see earlier), while other animals (both di/di and di/ +) went through sham operation. Eight days later a jugular catheter was implanted and after $48 \mathrm{~h}$ the swim test was completed.

\section{Anterior pituitary sensitivity to $C R H$}

In vivo testing of anterior pituitary sensitivity to CRH To test the sensitivity of the anterior pituitary to CRH, $40 \mathrm{ng} / \mathrm{kg} \mathrm{CRH}$ (Sigma) was injected i.v. into cannulated animals and blood samples were collected at $0,10,20,30,45$ and $60 \mathrm{~min}$.

In vitro testing: static incubation Pituitary $\mathrm{ACTH}$ secretion and cAMP content as well as the adrenal gland corticosterone secretion were assessed by static incubation (Stachura et al. 1985). Anterior pituitary and adrenal glands were obtained after death by decapitation between 0830 and 0930 . Each gland was chopped into eight pieces and preincubated in $1 \mathrm{ml}$ DMEM (Sigma-Aldrich) containing $2.5 \mathrm{~g}$ BSA/1 (Fraction V, Calbiochem, La Jolla, CA, USA) at $37^{\circ} \mathrm{C}$ under $95 \% \mathrm{O}_{2}-5 \% \mathrm{CO}_{2}$ atmosphere for $2 \times 1 \mathrm{~h}$. After preincubation, the pituitary fragments were incubated for $20 \mathrm{~min}$ with $5 \times 10^{-8} \mathrm{M} \mathrm{CRH}$ (for cAMP content) or $5 \times 10^{-11} \mathrm{M}$ CRH (for ACTH secretion; (Antoni \& Dayanithi 1990)) containing DMEM. For adrenal segments, the medium was collected and replaced with fresh media every $15 \mathrm{~min}$ six times with different doses of ACTH $\left(10^{-12} ; 10^{-11} ; 10^{-10} \mathrm{M}\right)$ added to the media. In the case of serial sampling, all data were expressed as percentage of the basal secretion measured in the first 15 min sample. At the conclusion of the experiment (after $20 \mathrm{~min}$ for hypohysis and at the end of each $15 \mathrm{~min}$ fraction for the adrenal gland), media were removed, centrifuged at $3000 \mathrm{~g}$ for $5 \mathrm{~min}$ and the supernatant stored at $-20{ }^{\circ} \mathrm{C}$ until analysis. Pituitary tissue from each tube was carefully removed and homogenised in $250 \mu \mathrm{l}$ of $0 \cdot 1 \mathrm{M} \mathrm{HCl}$ with $250 \mu \mathrm{l}$ of $0 \cdot 1 \mathrm{M}$ $\mathrm{HCl}$ wash and the homogenate was centrifuged at $3000 \boldsymbol{g}$ for $5 \mathrm{~min}$. A volume of $250 \mu \mathrm{l}$ of supernatant was stored at $-20{ }^{\circ} \mathrm{C}$, freeze dried then cAMP content was measured.

\section{Hormone measurement}

The concentrations of ACTH and corticosterone were measured by RIA, as described earlier (Zelena et al. 2008). The intraassay coefficients of variation for ACTH and corticosterone were $4 \cdot 7$ and $12 \cdot 3$ respectively. Immunoreactive cAMP was determined by the modification of the specific RIA described by Brooker et al. (1979). Our highly specific antibody (no. 309) developed against 2-O-succinylcAMP-HAS in goat has a cross-reactivity of $<0.001 \%$ for cGMP, ATP and AMP thereby allowing the direct determination of cAMP even in the presence of high concentration of ATP. The antibody was used in final dilution of 1:8000. 2'O-succinyl-cAMP tyrosine methylester iodinated by the chloramine $t$-method served as radioligand. Separation of bound and free fraction was performed with $1 \mathrm{ml}$ of ice-cold ethanol. The sensitivity of the assay was 
Table 1 Resting hormone and mRNA levels of the HPA axis. The mentioned parameters were summarised from different experimental series

\begin{tabular}{|c|c|c|c|c|c|c|}
\hline & $\begin{array}{l}\text { Crh mRNA in } \\
\text { PVN (\% of } \\
\mathrm{di} /+)\end{array}$ & $\begin{array}{l}\text { Pomc mRNA in } \\
\text { AL }(\% \text { of } \\
\text { di } /+)\end{array}$ & $\begin{array}{l}\text { ACTH }(\mathrm{fmol} / \mathrm{ml}) \\
\text { decap. }\end{array}$ & $\begin{array}{l}\text { ACTH }(\mathrm{fmol} / \mathrm{ml}) \\
\text { cannulated }\end{array}$ & $\begin{array}{l}\text { Corticosterone } \\
(\mathrm{pmol} / \mathrm{ml}) \\
\text { decap. }\end{array}$ & $\begin{array}{l}\text { Corticosterone }(\mathrm{pmol} / \mathrm{ml}) \\
\text { cannulated }\end{array}$ \\
\hline $\mathrm{di} /+$ & $100 \cdot 0 \pm 4 \cdot 7$ & $100 \cdot 0 \pm 3 \cdot 5$ & $23 \cdot 9 \pm 3 \cdot 0$ & $70 \cdot 6 \pm 10 \cdot 5^{\neq}$ & $137 \cdot 4 \pm 17 \cdot 6$ & $277 \cdot 4 \pm 41 \cdot 4^{\ddagger}$ \\
\hline$n$ & $21-$ & $28--$ & 136 & $83--2$ & 142 & $66--2$ \\
\hline $\mathrm{di} / \mathrm{di}$ & $135 \cdot 4 \pm 9 \cdot 2^{\dagger}$ & $111 \cdot 6 \pm 3.9 *$ & $21 \cdot 0 \pm 1 \cdot 5$ & $82 \cdot 8 \pm 10 \cdot 7^{\ddagger}$ & $175 \cdot 2 \pm 13 \cdot 7$ & $332 \cdot 7 \pm 43 \cdot 5^{\ddagger}$ \\
\hline$n$ & 24 & 30 & 135 & 75 & 140 & $63--2+3$ \\
\hline
\end{tabular}

${ }^{*} P<0 \cdot 05 ;{ }^{\dagger} P<0 \cdot 01$ versus $\mathrm{di} /+;{ }^{\ddagger} P<0 \cdot 05$ versus decapited.

decap., decapitated.

$0 \cdot 05 \mathrm{pmol} /$ tube. The intrassay variation was $7 \cdot 1 \%$. All samples from one experiment were measured in one assay.

\section{Statistical analysis}

Data were analysed by ANOVA using the ANOVA/MANOVA module of the STATISTICA 6.0 software package (Tulsa, OK, USA). In experiments where serial blood samples were collected, a repeated measure ANOVA was used (effect of time). Both one-way (genotype) and two-way (1: genotype (di/ + , di/di, $+/+$ or Wistar or desmopressin), 2: stress) ANOVAs were used to analyse data based upon the number of dependent variables in an experiment. Multiple pairwise comparisons were made by the Newman-Keuls method. Data are expressed as mean \pm s.E.M. and the level of significance was set at $P<0 \cdot 05$.

\section{Results}

\section{Basal levels}

The di/di rats had significantly higher resting Crh mRNA levels in their PVN (genotype: $F_{(1,43)}=14056 ; P<0 \cdot 01$; Table 1) and elevated Pomc mRNA level in the anterior lobe of the pituitary (genotype: $F_{(1,56)}=1942 ; P<0 \cdot 05$; Table 1) compared with heterozygous littermates.

The resting hormone levels from different experimental series are summarised in Table 1. Cannulation of animals resulted in higher resting $\mathrm{ACTH}$ and corticosterone plasma levels than those following decapitation (mode of blood sampling, ACTH: $F_{(1,425)}=78 \cdot 5$; corticosterone:
$\left.F_{(1,407)}=32 \cdot 4 ; \quad P<0 \cdot 01\right)$. Genotype did not have a significant effect on basal hormone levels, although there was a trend for elevated corticosterone in $\mathrm{di} / \mathrm{di}$ rats following decapitation (genotype: $F_{(1,280)}=2 \cdot 87 ; P=0 \cdot 09$ ).

Since these data (elevated Crh mRNA in PVN, enhanced Pomc mRNA levels in anterior lobe and a tendency for elevated basal corticosterone levels) are typically observed during chronic stress. We decided to collect somatic measures to determine whether peripheral endpoints were similarly affected (Table 2). The main difference was the smaller body and tissue weight of di/di animals (genotype, body weight: $F_{(1,203)}=55 \cdot 2$; thymus: $F_{(1,203)}=19 \cdot 8$; adrenal gland: $F_{(1,183)}$ $=27 \cdot 8 ; P<0 \cdot 01)$. However, there was no significant difference in the relative organ weights between the two genotypes.

\section{Daily rhythms}

The well-established rhythmic changes were present both in ACTH and corticosterone levels with lowest levels between 2 and $6 \mathrm{~h}$ of the light phase and the highest levels detected between 14 and $22 \mathrm{~h}$ (beginning $2 \mathrm{~h}$ after the onset of the dark phase; Fig. 1, time, ACTH: $F_{(23,138)}=5 \cdot 44$; corticosterone: $\left.F_{(23,184)}=4 \cdot 80 ; P<0 \cdot 01\right)$. There was no significant difference between the two genotypes in net secretion (area under the curve (AUC) ACTH (fmol/ml): $\mathrm{di} /+546 \cdot 4 \pm 95 \mathrm{di} / \mathrm{di} 460 \cdot 6 \pm 73$ corticosterone $(\mathrm{pmol} / \mathrm{ml})$ : $\mathrm{di} /+6891 \cdot 5 \pm 615 \mathrm{di} / \mathrm{di} 6981 \cdot 1 \pm 492)$ or in maximal hormone changes during the day (ACTH $(\mathrm{fmol} / \mathrm{ml})$ : $\mathrm{di} /+85 \cdot 6 \pm 24, \mathrm{di} / \mathrm{di} 86 \cdot 4 \pm 7$ corticosterone $(\mathrm{pmol} / \mathrm{ml})$ $\mathrm{di} /+698 \cdot 3 \pm 100, \mathrm{di} / \mathrm{di} 615 \cdot 0 \pm 37)$ for both $\mathrm{ACTH}$ and corticosterone.

Table 2 Somatic differences between di/ + and di/di animals. The mentioned parameters were summarised from different experimental series

\begin{tabular}{|c|c|c|c|c|c|}
\hline & Body weight (g) & Thymus weight (mg) & $\begin{array}{l}\text { Relative thymus } \\
\text { weight (mg/kg) }\end{array}$ & Adrenal gland (mg) & $\begin{array}{l}\text { Relative adrenal } \\
\text { gland weight } \\
(\mathrm{mg} / \mathrm{kg})\end{array}$ \\
\hline $\mathrm{di} /+$ & $364 \cdot 5 \pm 5 \cdot 6$ & $363 \cdot 1 \pm 9 \cdot 0$ & $1015 \cdot 6 \pm 28 \cdot 9$ & $42 \cdot 1 \pm 0 \cdot 8$ & $114 \cdot 1 \pm 2 \cdot 2$ \\
\hline$n$ & 102 & 102 & $98--1-2$ & $92-1-2$ & $88--5$ \\
\hline $\mathrm{di} / \mathrm{di}$ & $309 \cdot 0 \pm 5 \cdot 0^{+}$ & $306 \cdot 8 \pm 8 \cdot 9^{+}$ & $996 \cdot 8 \pm 29 \cdot 7$ & $36 \cdot 5 \pm 0 \cdot 8^{+}$ & $115 \cdot 9 \pm 2 \cdot 1$ \\
\hline$n$ & 103 & 103 & $99--$ & $93-$ & 89 \\
\hline
\end{tabular}

${ }^{*} P<0 \cdot 05 ;{ }^{+} P<0 \cdot 01$ versus $\mathrm{di} /+{ }^{\ddagger} P<0 \cdot 05$ versus decapited. 

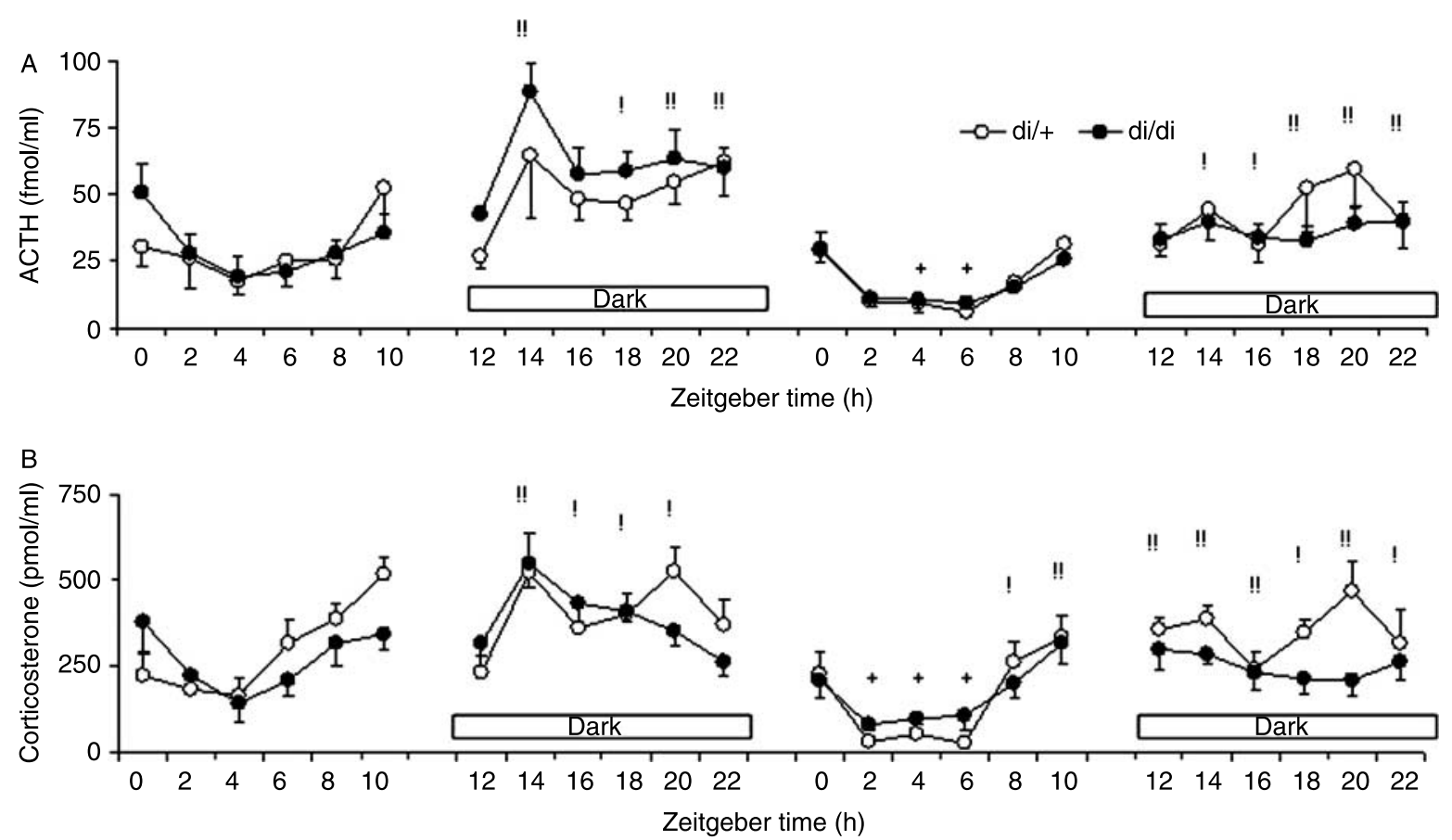

Figure 1 Rhythmic changes in plasma $\mathrm{ACTH}((\mathrm{A}) \mathrm{fmol} / \mathrm{ml})$ and corticosterone ((B) pmol/ml) levels in Brattleboro rats. Serial blood samples were collected on two consecutive days every $2 \mathrm{~h}$ via a catheter in the vena jugularis. Separate group of animals were used for light phase (lights on at $7 \mathrm{~h}$; samples 0-12) and dark phase (kept in reversed cycle, lights on at $22 \mathrm{~h}$; samples 12-24). The time when the lights were switched on is referred to as Zeitgebertime $0 . n=7-9$ The effect of time was statistically significant for both hormones $(P<0 \cdot 01) .{ }^{+} P<0 \cdot 05$, ${ }^{+}+P<0 \cdot 01$ the time point versus $\left.0 \mathrm{~h} ; !\right) P<0 \cdot 05 ; ! ! P<0 \cdot 01$ the time point versus $2-4-6 \mathrm{~h}$ (lower levels).

Stress studies with single timepoint (decapitation)

Novelty stress In di/ + animals, both the ACTH and corticosterone plasma levels were elevated at the end of 10 min of novelty stress (Fig. 2; stress, ACTH: $F_{(1,34)}=9 \cdot 89$; corticosterone: $\left.F_{(1,34)}=48 \cdot 88 ; P<0 \cdot 01\right)$. The resting plasma levels were similar in $\mathrm{di} /+$ and di/di animals. Novelty stress did not induce ACTH elevations in di/di rats (stress-genotype interaction: $\left.F_{(1,34)}=5.72 ; P<0.05\right)$; however, the rise in corticosterone was similar to that seen in $\mathrm{di} /+$ animals (no significant interaction).

Social avoidance There was no significant effect of genotype on the ACTH of corticosterone response to $8 \mathrm{~min}$ in the social avoidance box (Table 3).

Elevated plus-maze In response to the EPM, plasma ACTH levels were significantly lower in di/di rats compared with heterozygous littermates (Table 3 , genotype: $F_{(1,18)}=4 \cdot 91$; $P<0 \cdot 05)$. By contrast, the plasma corticosterone levels from the same animals were similar between the two genotypes.

LPS challenge One hour after i.p. injection of LPS $(300 \mu \mathrm{g} / \mathrm{kg})$ plasma ACTH and corticosterone levels were significantly elevated in $\mathrm{di} /+$ rats (Table 3 , treatment, ACTH: $\quad F_{(1,36)}=9 \cdot 38 ; \quad$ corticosterone: $F_{(1,36)}=20 \cdot 3$; $P<0 \cdot 01$; control levels can be found in Table 1). Although the effect of genotype was not significant for either hormone, there was a significant increase in ACTH in di/ + animals that did not occur in di/di rats, in contrast to the big elevation in corticosterone levels observed for both genotypes.

Ether inhalation Ten minutes after the onset of ether inhalation plasma $\mathrm{ACTH}$ and corticosterone levels were significantly elevated (Table 3, stress, ACTH: $F_{(1,67)}=287 \cdot 3$; corticosterone: $\left.F_{(1,67)}=110 \cdot 8 ; P<0 \cdot 01\right)$. The genotype had no effect on the observed elevations.

\section{Stress studies with serial blood sampling}

Hypertonic saline The combined effect of i.p. injection and volume load (controls on Fig. 3A) induced a small, although statistically significant, elevation in plasma ACTH (time: $\left.F_{(5,85)}=8 \cdot 11 ; P<0 \cdot 01\right)$ with lower levels in AVPdeficient rats (genotype: $F_{(1,17)}=8 \cdot 34 ; P=0 \cdot 01$ ). At the same time, the corticosterone elevation did not differ between genotypes (Fig. 3B controls; only the effect of time was significant: $\left.F_{(5,85)}=21 \cdot 2 ; P<0 \cdot 01\right)$.

Injecting hypertonic saline into the peritoneal cavity stimulates ACTH secretion within $5 \mathrm{~min}$, and the effect persists for $2 \mathrm{~h}$ (treatment: $F_{(1,36)}=90 \cdot 5$, time: $F_{(5,180)}=47 \cdot 3$, treatment $X$ time: $\left.F_{(5,180)}=31 \cdot 0 ; P<0 \cdot 01\right)$. In AVP-deficient animals, the hypertonic saline-induced ACTH elevation was lower only at $1 \mathrm{~h}(P=0 \cdot 05)$, and there was not a significant 

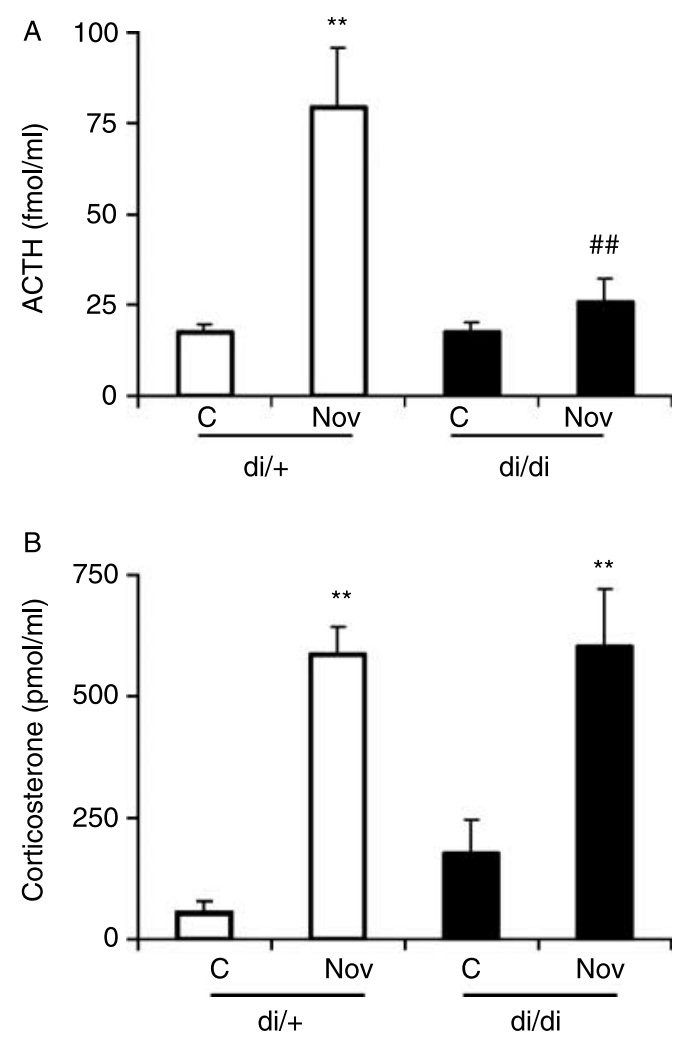

Figure 2 Novelty stress in Brattleboro rats. Plasma ACTH ((A) $\mathrm{fmol} / \mathrm{ml}$ ) levels were significantly elevated in $\mathrm{di} /+$ but not in $\mathrm{di} / \mathrm{di}$ rats, while the corticosterone $((B) \mathrm{pmol} / \mathrm{ml})$ levels were elevated in both genotypes. $n=8-12$ C-control, unstressed; Nov- at the end of 10 min novelty ${ }^{* *} P<0 \cdot 01$ versus control; ${ }^{\sharp} P<0 \cdot 01$ versus $\mathrm{di} /+$.

overall effect of genotype (treatment $\times$ time $\times$ genotype interaction: $\left.F_{(5,180)}=2 \cdot 77 ; P<0 \cdot 05\right)$. The accompanying corticosterone levels increased gradually until $30 \mathrm{~min}$ and remained elevated until the end of the examination period (treatment: $F_{(1,36)}=5 \cdot 53$, time: $F_{(5,180)}=77 \cdot 5$, treatment $X$ time: $\left.F_{(5,180)}=5 \cdot 28 ; P<0 \cdot 01\right)$. Genotype had no effect on the corticosterone response to hypertonic saline.
Anaphylactoid reaction Intravenous saline injection induced a very mild ACTH secretion $1 \mathrm{~h}$ after its administration in both genotypes (Fig. 3C; time: $F_{(6,102)}=3 \cdot 38$; $P<0 \cdot 01)$. The corticosterone levels were significantly elevated and did not differ between the two genotypes (Fig. 3D; time: $F_{(6,102)}=9 \cdot 97 ; P<0 \cdot 01$, between 30 and $\left.120 \mathrm{~min}\right)$.

Injecting the egg white preparation into the vena jugularis induced a remarkable elevation in the ACTH and corticosterone, with a peak in $\mathrm{ACTH}$ at 15 and $30 \mathrm{~min}$ and a persisting corticosterone elevation from $15 \mathrm{~min}$ through $2 \mathrm{~h}$ (treatment, ACTH: $F_{(1,39)}=165 \cdot 0$; corticosterone: $F_{(1,39)}=15 \cdot 17$; time, ACTH: $F_{(6,234)}=52 \cdot 7$; corticosterone: $F_{(6,234)}=41 \cdot 3$; treatment $\times$ time, ACTH: $F_{(6,234)}=51 \cdot 5 ; \quad$ corticosterone: $\left.F_{(6,234)}=6 \cdot 84 ; \quad P<0 \cdot 01\right)$. The ACTH elevation was significantly smaller in AVP-deficient rats (genotype: $F_{(1,39)}$ $=5 \cdot 6$, treatment $\times$ genotype: $F_{(1,39)}=7 \cdot 11$, time $\times$ genotype: $F_{(6,234)}=2 \cdot 84$, treatment $X$ time $\times$ genotype: $F_{(6,234)}=2 \cdot 31$; $P<0 \cdot 05)$. In di/ + animals, the ACTH elevation disappeared at $90 \mathrm{~min}$, while in di/di animals the concentration of ACTH returned to basal levels by $1 \mathrm{~h}$. By contrast, the corticosterone elevation was similar between the two genotypes.

Footshock Placing the animals into the footshock box without administering shocks resulted in a significant elevation of their plasma ACTH and corticosterone levels and was not affected by genotype (Fig. 3E and F.; time, ACTH: $F_{(5,110)}=$ $22 \cdot 3$; corticosterone: $\left.F_{(5,110)}=58 \cdot 9 ; P<0 \cdot 01\right)$.

Electrical shock was able to induce a further ACTH rise being similar in di $/+$ and di/di rats (footshock: $F_{(1,46)}=5 \cdot 99$; $P<0 \cdot 05$; footshock $\times$ time: $\left.F_{(5,230)}=7 \cdot 04 ; P<0 \cdot 01\right)$. At the same time, there was only a trend for a shock-induced increase in corticosterone (footshock: $F_{(1,45)}=3 \cdot 13, P=0 \cdot 08$; footshock $\times$ time: $\left.F_{(5,225)}=2 \cdot 87, P<0 \cdot 05\right)$ and genotype did not affect the response.

Restraint Putting the animals into a restraint chamber stimulated both ACTH and corticosterone secretion within 5 min (Fig. $4 \mathrm{~A}$ and B; time, ACTH: $F_{(6,222)}=24 \cdot 4$; corticosterone: $\left.F_{(6,216)}=50 \cdot 9 ; \quad P<0 \cdot 01\right)$. The highest ACTH levels were visible at $15 \mathrm{~min}$ and remained stable until the end of the stress ( $1 \mathrm{~h}$ ) but went back to basal levels by

Table 3 Plasma ACTH and corticosterone levels at one time-point after onset of a stimulus

\begin{tabular}{|c|c|c|c|c|c|}
\hline & \multirow[b]{2}{*}{ Time of stimulus (min) } & \multicolumn{2}{|l|}{ ACTH $(\mathrm{fmol} / \mathrm{ml})$} & \multicolumn{2}{|c|}{ Corticosterone (pmol/ml) } \\
\hline & & $\mathrm{di} /+$ & $\mathrm{di} / \mathrm{di}$ & $\mathrm{di} /+$ & $\mathrm{di} / \mathrm{di}$ \\
\hline $\begin{array}{l}\text { Social avoidance } \\
n\end{array}$ & $3+5$ & $\begin{array}{l}110 \cdot 5 \pm 17 \cdot 6 \\
18\end{array}$ & $\begin{array}{l}83 \cdot 5 \pm 22 \cdot 7 \\
9\end{array}$ & $\begin{array}{l}339 \cdot 5 \pm 76 \cdot 5 \\
7\end{array}$ & $\begin{array}{l}326 \cdot 0 \pm 50 \cdot 4 \\
5\end{array}$ \\
\hline EPM & 5 & $209 \cdot 2 \pm 31 \cdot 4$ & $121 \cdot 6 \pm 20 \cdot 4^{\ddagger}$ & $499 \cdot 2 \pm 61 \cdot 4$ & $534 \cdot 7 \pm 35 \cdot 6$ \\
\hline$n$ & & $6--1-2$ & $14-$ & $6--1-2$ & $14--$ \\
\hline LPS & 60 & $295 \cdot 2 \pm 106 \cdot 1^{*}$ & $192 \cdot 9 \pm 98 \cdot 7$ & $962 \cdot 9 \pm 201 \cdot 4^{\dagger}$ & $864 \cdot 8 \pm 270 \cdot 5^{+}$ \\
\hline$n$ & & $10--$ & $10--$ & $10--$ & $10--$ \\
\hline Ether & $3+7$ & $1027 \cdot 6 \pm 75 \cdot 8^{+}$ & $999 \cdot 8 \pm 89 \cdot 3^{\dagger}$ & $721 \cdot 1 \pm 94 \cdot 1^{+}$ & $791 \cdot 8 \pm 73 \cdot 8^{+}$ \\
\hline$n$ & & 19 & $16--x$ & $19-2$ & $16-7$ \\
\hline
\end{tabular}

${ }^{*} P<0.05 ;{ }^{\dagger} P<0.01$ versus control, untreated rats of the same genotype (control levels can be found in Table 1 ); ${ }^{\ddagger} P<0 \cdot 05$ versus di/ + rats. 

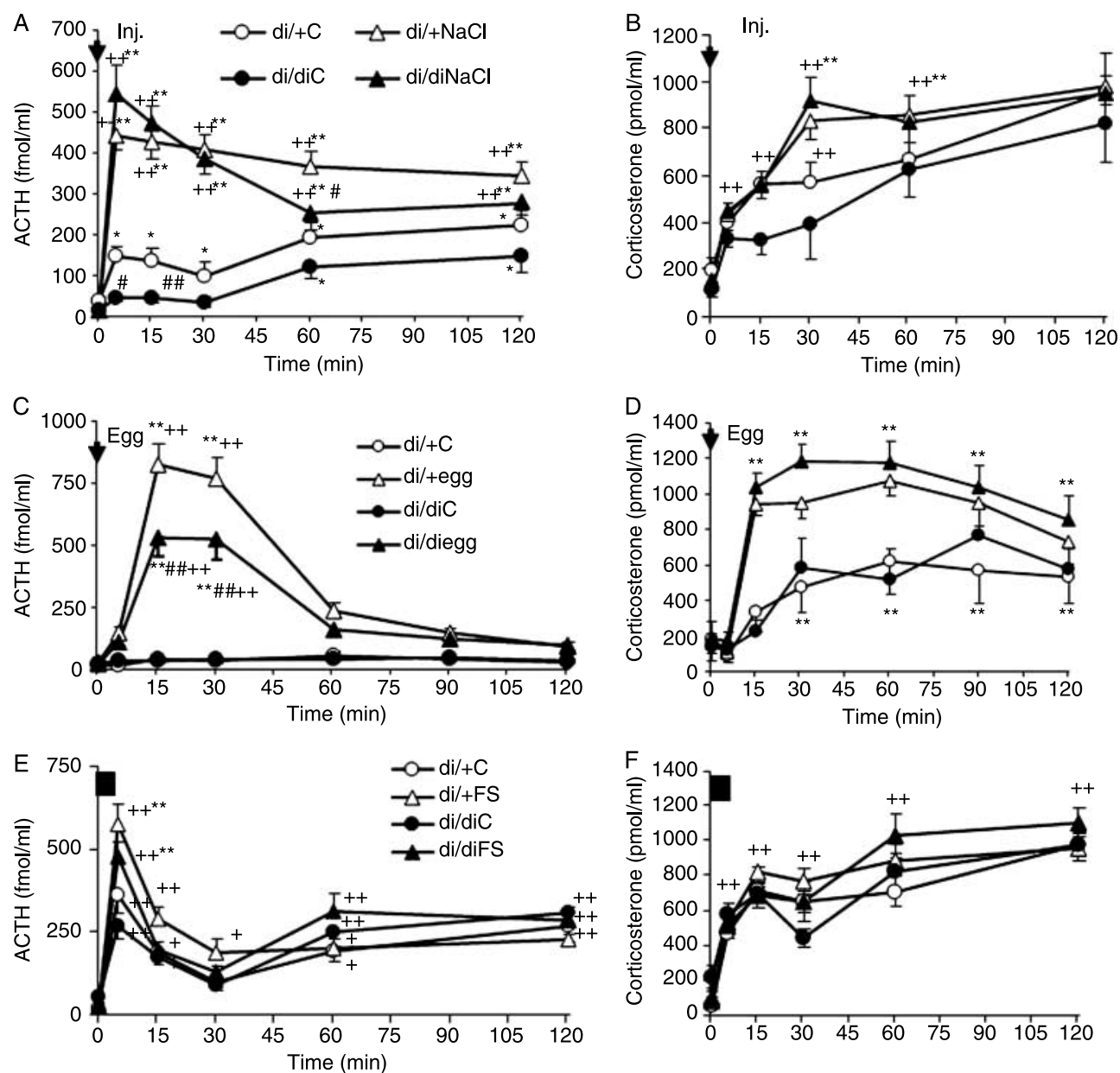

Figure 3 Serial blood sampling from cannulated Brattleboro animals after i.p. saline $(1.5 \mathrm{ml} / 100 \mathrm{~g})$, hypertonic saline $(1.5 \mathrm{M})$ treatment $(A$ and $B ; n=7-12)$, i.v. administration of saline/egg white preparation (C and D; $n=9-13$ ) or new box/footshock (E and F; $n=10-17)$. ACTH (fmol/ml; A, C and E) levels were elevated in all five cases (volume load (control on A), hypertonic saline, egg white, new box or footshock). The $\mathrm{di} / \mathrm{di}$ animals had lower elevation after volume load and at $1 \mathrm{~h}$ after i.p. hypertonic saline (A) and after egg white injection $(C)$, but not after placing them into the footshock box, or after footshock (E). The corticosterone $\left(\mathrm{pmol} / \mathrm{ml}, \mathrm{B}, \mathrm{D}\right.$ and F) plasma levels were elevated throughout without any effect of genotype. ${ }^{+} P<0 \cdot 05$, ${ }^{+} P<0 \cdot 01$ vs 0 min; ${ }^{*} P<0 \cdot 05,{ }^{* *} P<0.01$ versus control; ${ }^{\sharp} P<0 \cdot 05,{ }^{\# \#} P<0 \cdot 01$ versus $\mathrm{di} /+$.

$120 \mathrm{~min}$ (Fig. 4A). By contrast, the corticosterone levels elevated gradually throughout the stimulus and remained stable even $1 \mathrm{~h}$ after stressor cessation (Fig. 4B). The AVPdeficient rats revealed smaller elevations during the stress for both hormones (genotype, ACTH: $F_{(1,37)}=12 \cdot 08$; corticosterone: $F_{(1,36)}=7 \cdot 38$; time $\times$ genotype, ACTH: $F_{(6,222)}=5 \cdot 29$; corticosterone: $\left.F_{(6,216)}=2 \cdot 93 ; P<0 \cdot 01\right)$.

Social defeat Aggressive interaction is a significant stimulus to rats inducing long-lasting ACTH (Fig. 4C) and corticosterone (Fig. 4D) elevations in the plasma visible even $110 \mathrm{~min}$ after stressor cessation (time, ACTH: $F_{(5,175)}=14 \cdot 83$; corticosterone: $\left.F_{(5,170)}=32 \cdot 06 ; P<0 \cdot 01\right)$. The lack of AVP resulted in a reduced activation of the HPA axis, which reduced both hormone levels (time $\times$ genotype, ACTH:
$F_{(5,175)}=2 \cdot 25, \quad P=0 \cdot 05 ;$ corticosterone: $F_{(5,170)}=32 \cdot 06$, $P<0 \cdot 01)$.

\section{Special controls}

Ulcerogenic cold-immobilisation Ulcerogenic stimulus ( $4 \mathrm{~h}$ cold-immobilisation) resulted in the formation of haemorrhagic erosion with similar severity in all three animal groups (erosion area in Wistar: $4.98 \pm 1.0 \mathrm{~mm}^{2}$; $\mathrm{di} /+$ : $5.06 \pm 1.6 \mathrm{~mm}^{2}$; di/di: $\left.4.74 \pm 1.4 \mathrm{~mm}^{2}\right)$. The ACTH levels of these animals were elevated with a peak at $30 \mathrm{~min}$ (Fig. 5A; time: $\left.F_{(5,45)}=53 \cdot 1 ; P<0 \cdot 01\right)$. Both di/ + and Wistar rats showed similar changes in ACTH throughout, while $\mathrm{di} / \mathrm{di}$ animals had reduced $\mathrm{ACTH}$ at the $1 \mathrm{~h}$ time point (time $\times$ group: $\left.F_{(10,45)}=4 \cdot 46 ; P<0 \cdot 01\right)$. The corticosterone 

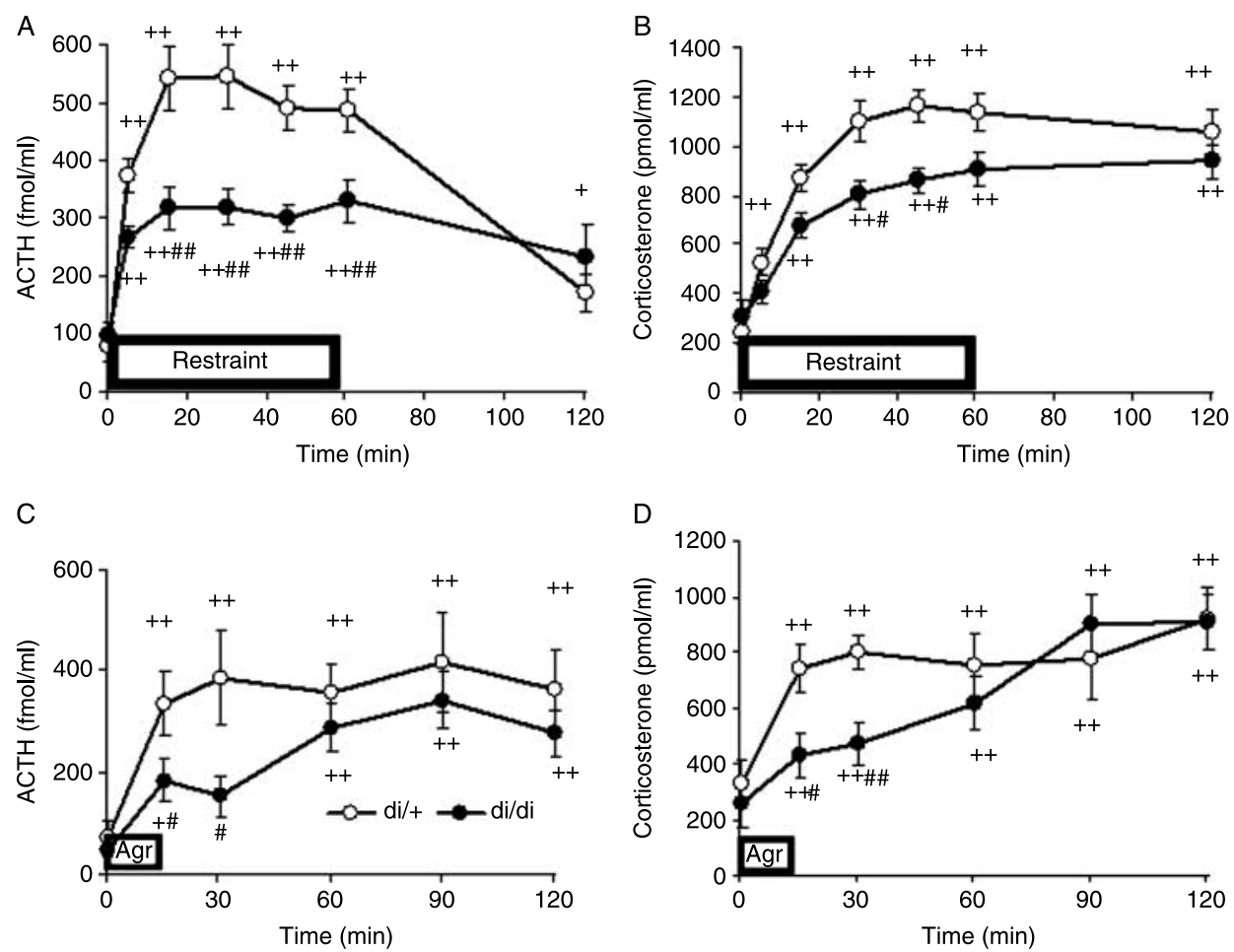

Figure 4 Serial blood sampling from cannulated Brattleboro rats during $1 \mathrm{~h}$ restraint $(\mathrm{A}$ and $\mathrm{B} ; n=26-28)$ and after 10 min aggressive interaction (Agr; C and D; $n=24-26)$. Both ACTH (fmol/ml; A and C) and corticosterone $\left(\mathrm{pmol} / \mathrm{ml}, \mathrm{B}\right.$ and D) plasma levels were elevated with smaller elevations in $\mathrm{di} / \mathrm{di}$ rats. ${ }^{+} P<0 \cdot 05$; ${ }^{++} P<0.01$ vs 0 min; ${ }^{\#} P<0 \cdot 05,{ }^{\#} P<0 \cdot 01$ versus $\mathrm{di} /+$.

levels increased through $1 \mathrm{~h}$ then remained stable (Fig. 5B; time: $\left.F_{(5,40)}=25 \cdot 5 ; \quad P<0 \cdot 01\right)$ and was not different between groups.

Hypoglycaemia The blood glucose levels of all three genotypes were similar after $18 \mathrm{~h}$ fasting $(+/+: 4 \cdot 67$ $\pm 0.1 \mathrm{mmol} / \mathrm{l} ; \mathrm{di} /+: \quad 4.62 \pm 0.2 \mathrm{mmol} / \mathrm{l} ; \mathrm{di} / \mathrm{di}: \quad 4 \cdot 45$ $\pm 0 \cdot 2 \mathrm{mmol} / \mathrm{l}$ ). Actrapid injection (i.p.) significantly decreased blood glucose in all groups, with the lowest concentration in $\mathrm{di} / \mathrm{di}$ rats $(+/+: 2 \cdot 48 \pm 0.05 \mathrm{mmol} / \mathrm{l}$; $\mathrm{di} /+: 2 \cdot 29 \pm 0.05 \mathrm{mmol} / \mathrm{l} ; \mathrm{di} / \mathrm{di}: 2 \cdot 0 \pm 0 \cdot 1 \mathrm{mmol} / \mathrm{l}$; treatment: $F_{(1,72)}=439 \cdot 1, P<0 \cdot 01$; genotype: $F_{(2,72)}=3 \cdot 52$, $P<0 \cdot 05)$. The fall in the blood glucose level resulted in a huge ACTH and corticosterone elevation in all three genotypes (Fig. 5C and D; treatment, ACTH: $F_{(1,71)}$ $=359 \cdot 5$, corticosterone: $\left.F_{(1,70)}=132.5 ; \quad P<0 \cdot 01\right)$. The Actrapid induced ACTH elevation was smaller in di/di rats compared with both $+/+$ and $\mathrm{di} /+$ controls, while there was no difference between $+/+$ and $\mathrm{di} /+$ rats (Fig. $5 \mathrm{C}$; genotype: $F_{(2,71)}=10 \cdot 66$, treatment $\times$ genotype: $F_{(2,71)}=12 \cdot 48$; $P<0 \cdot 01)$. There was no difference in corticosterone elevation between groups.

Forced swim Replacing the peripheral AVP by an osmotic minipump leads to a significant reduction in water intake in di/di animals (di/+: $34.8 \pm 1.9 \mathrm{ml} /$ day; di/di: 103.9 $\pm 8.3 \mathrm{ml} / \mathrm{day} ; \mathrm{di} / \mathrm{di}$ with DDAVP: $32.6 \pm 1.9 \mathrm{ml} /$ day; group: $\left.F_{(2,22)}=5 \cdot 24 ; P<0 \cdot 05\right)$. Forcing the animals to swim for $10 \mathrm{~min}$ induced a significant ACTH elevation with a peak at $5 \mathrm{~min}$ in di/ + rats (Fig. $5 \mathrm{E}$; time: $F_{(5,115)}$ $=13 \cdot 6 ; P<0 \cdot 01)$. This elevation was significantly reduced in the absence of central AVP, as compensation of the peripheral AVP deficiency by DDAVP was unable to restore the ACTH elevation (group: $F_{(2,23)}=4 \cdot 43$, time $\times$ group: $\left.F_{(10,115)}=2 \cdot 21 ; P=0 \cdot 02\right)$. Corticosterone levels were also elevated with the highest level seen $20 \mathrm{~min}$ after the end of the forced swimming test (Fig. 5F; time: $F_{(5,115)}=19 \cdot 6$; $P<0 \cdot 01)$. The corticosterone reducing effect of AVP deficiency was not statistically significant (groups: $F_{(2,23)}$ $=3 \cdot 39, P=0 \cdot 051 ;$ time $\times$ group: $\left.F_{(10,115)}=1 \cdot 75, P=0 \cdot 07\right)$.

\section{Sensitivity of the anterior pituitary}

To study the in vivo sensitivity of the anterior pituitary we injected animals with $\mathrm{CRH}(40 \mathrm{ng} / \mathrm{kg}$ i.v.) and observed an activation of $\mathrm{ACTH}$ and corticosterone secretion (Fig. 6A and B; time, ACTH: $F_{(5,65)}=11 \cdot 9$, corticosterone: $F_{(5,65)}=8 \cdot 05$; $P<0 \cdot 01)$. The ACTH changes were significantly smaller in di/di rats (Fig. 6A; genotype: $F_{(1,13)}=9 \cdot 51 ; P<0 \cdot 01$ ), while the corticosterone levels were similar in both genotypes. 
A

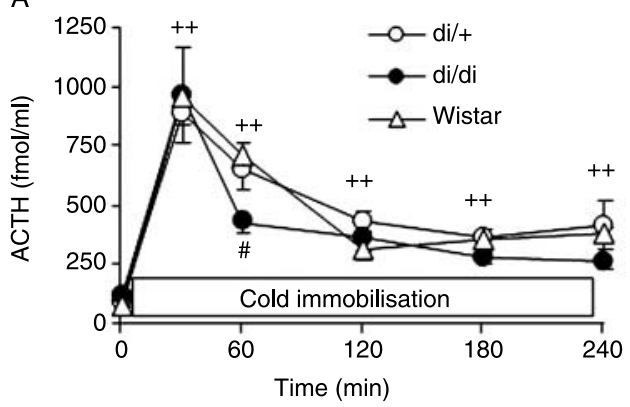

C

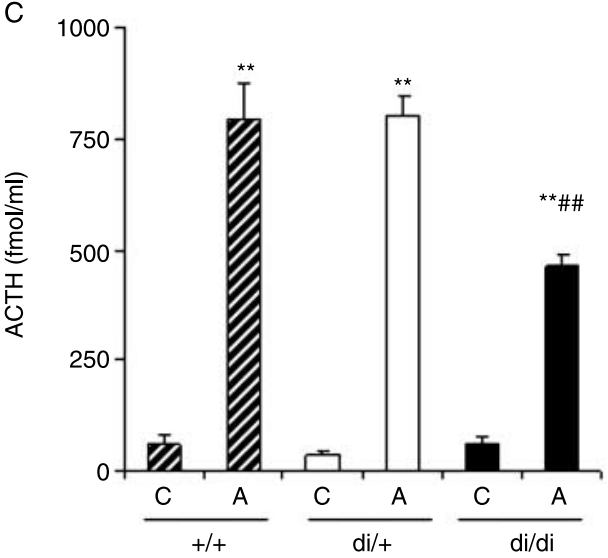

$\mathrm{E}$

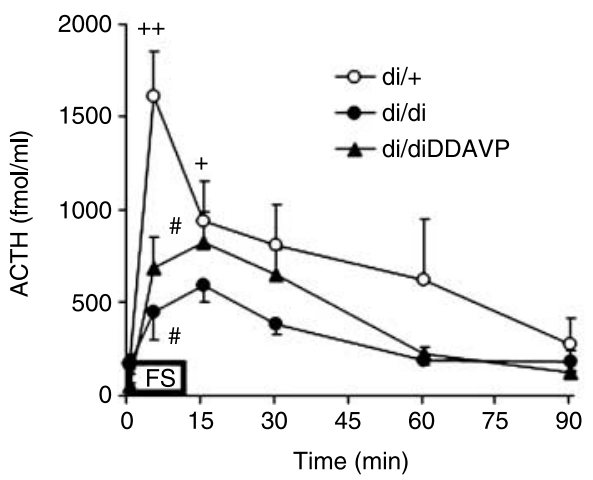

B
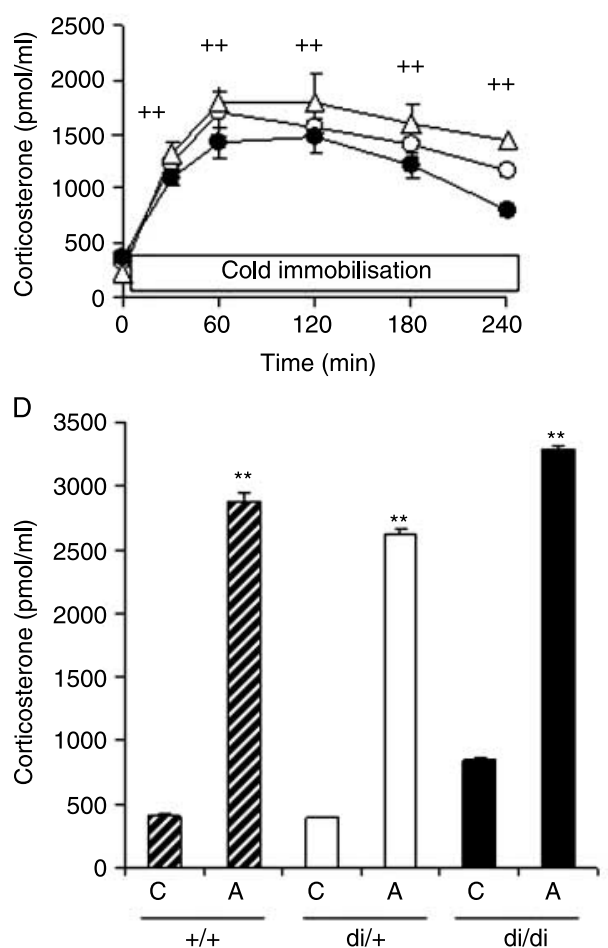

$\mathrm{F}$

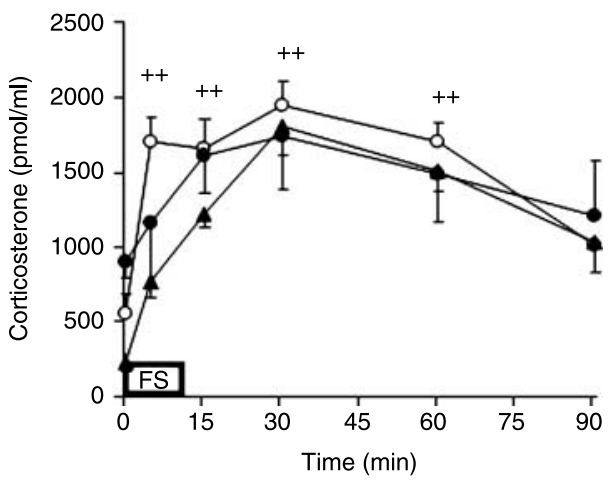

Figure 5 Response to $4 \mathrm{~h}$ cold immobilisation (A and $\mathrm{B} ; n=10-12$; Wistar), i.p. actrapid induced hypoglycaemia ( $C$ and $D ; n=12-14 ;+/+$ ) and 10 min forced swimming ( $E$ and $F ; n=5-12$; peripheral DDAVP in minipump). In all experiments there was at least one time point when the stress-induced ACTH $(\mathrm{fmol} / \mathrm{ml} ; \mathrm{A}, \mathrm{C}$ and $\mathrm{D})$ elevations were smaller in di/di rats. Wistar $(\mathrm{A})$ and $+/+$ rats $(\mathrm{C})$ showed similar profile to di/ + animals while replacing the peripheral AVP did not restore the effect of AVP deficiency (E). The corticosterone (pmol/ml; B, D and F) response was not different between groups. ${ }^{+} P<0 \cdot 05,{ }^{++} P<0 \cdot 01 \mathrm{vs}$ $0 \mathrm{~min} ;{ }^{* *} P<0 \cdot 01$ versus control; ${ }^{\sharp} P<0 \cdot 05,{ }^{\#} P<0 \cdot 01$ versus $\mathrm{di} /+$.

In an in vitro static incubation system the presence of $\mathrm{CRH}$ in the medium for $20 \mathrm{~min}$ resulted in a significant elevation in both cAMP content (Fig. 6C; due to $5 \times 10^{-8} \mathrm{M} \mathrm{CRH}$; treatment: $\left.F_{(1,35)}=45 \cdot 6 ; \quad P<0 \cdot 01\right)$ and ACTH secretion (Fig. $6 \mathrm{D}$; due to $5-10^{-11} \mathrm{M} \mathrm{CRH}$; treatment: $F_{(1,38)}$ $=107 \cdot 4 ; P<0 \cdot 01)$ from anterior pituitary fragments. The absence of AVP in di/di rats led to reduced ACTH secretion $(2 \cdot 2$-fold increase in $\mathrm{di} / \mathrm{di}$ animals versus $3 \cdot 7$-fold increase in di/ + rats; genotype: $F_{(1,38)}=18 \cdot 96$, treatment $\times$ genotype: $\left.F_{(1,38)}=16 \cdot 76 ; P<0 \cdot 01\right)$ without a significant difference in cAMP levels.

\section{Sensitivity of the adrenal gland}

There was a dose-dependent increase in net corticosterone secretion (Fig. 7A; AUC; treatment: $F_{(2,63)}=24 \cdot 4 ; P<0 \cdot 01$ ) 

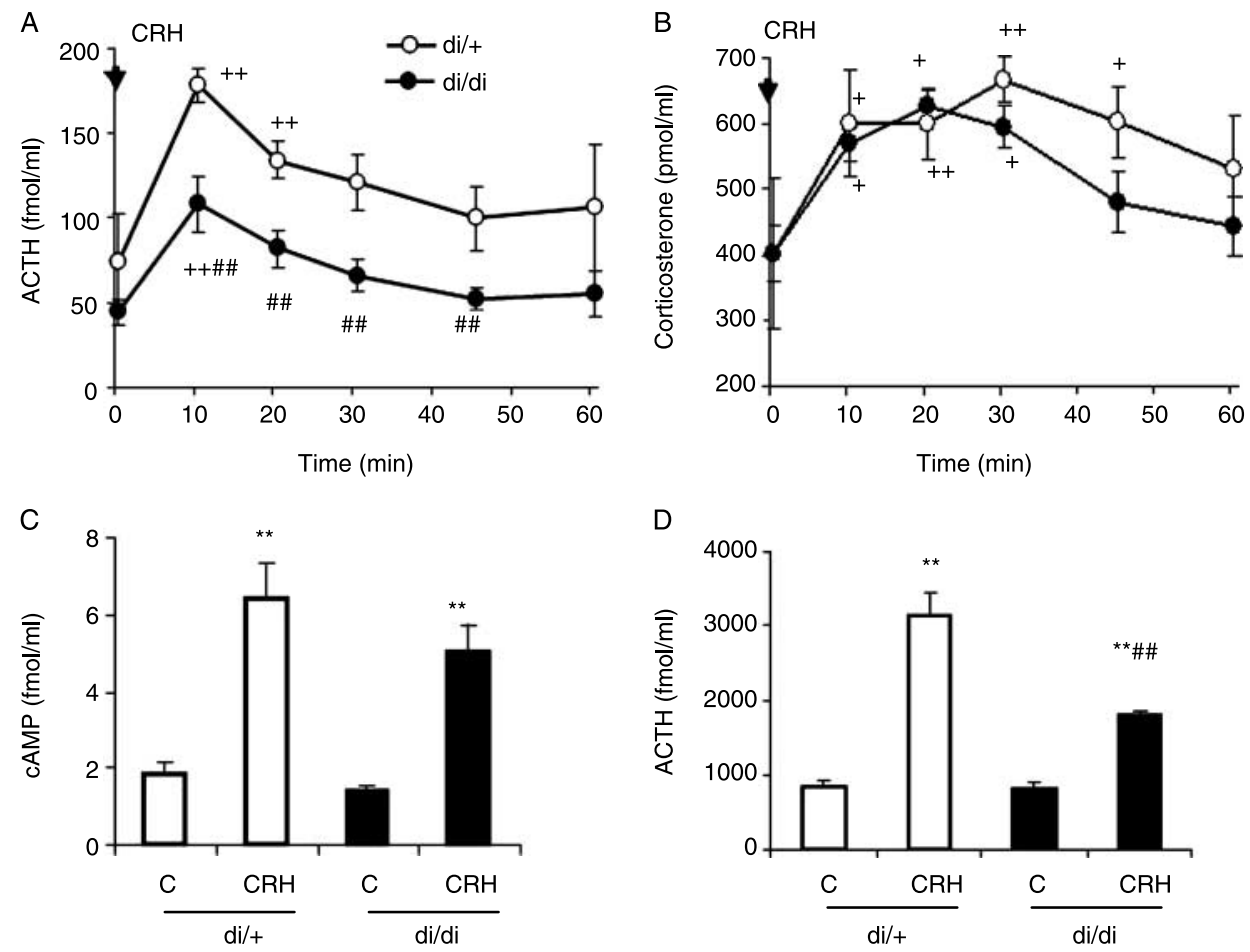

Figure 6 Sensitivity of the anterior pituitary to CRH. In vivo administration of $40 \mathrm{ng} / \mathrm{kg} \mathrm{CRH}$ (i.v.; $\mathrm{A}$ and $\mathrm{B} ; n=6-9)$ resulted in a significant elevation of both $\mathrm{ACTH}(\mathrm{fmol} / \mathrm{ml}, \mathrm{A})$ and corticosterone $(\mathrm{pmol} / \mathrm{ml}, \mathrm{B})$ with smaller ACTH rises in di/di animals. In vitro studies show both that cAMP content ( $\mathrm{C}$; due to $\left.5 \times 10^{-8} \mathrm{M} \mathrm{CRH} ; n=9-10\right)$ and $\mathrm{ACTH}$ secretion (D; due to $5-10^{-11} \mathrm{M} \mathrm{CRH}$; $n=10-11)$ were enhanced by $\mathrm{CRH}$ with a smaller ACTH response in di/di rats. ${ }^{+} P<0 \cdot 05$, ${ }^{++} P<0 \cdot 01$ vs 0 min; ${ }^{* *} P<0 \cdot 01$ versus control; ${ }^{\#} P<0 \cdot 01$ versus $\mathrm{di} /+$.

in response to ACTH $\left(10^{-12}, 10^{-11}, 10^{-10} \mathrm{M}\right)$. The increase was significantly lower in di/di rats (genotype: $\left.F_{(1,63)}=17 \cdot 13 ; \quad P<0 \cdot 01\right)$. The lowest dose significantly elevated corticosterone secretion from the adrenal gland being maximal in the post-test fraction (Fig. 7B; time: $\left.F_{(5,105)}=41 \cdot 6 ; \quad P<0 \cdot 01\right)$. The increase was significantly smaller in di/di rats (genotype: $F_{(1,21)}=8 \cdot 3$, treatment Xgenotype: $\left.F_{(5,105)}=3 \cdot 95 ; P<0 \cdot 01\right)$.

\section{Discussion}

Our work is the first to use such a wide range of stressors to better define the role of AVP in the acute HPA response to stress in Brattleboro rats. The present findings show that the role of AVP is indeed important for the regulation of ACTH secretion during exposure to acute stimuli and that the magnitude of AVP contribution in stress-induced HPA activity is context dependent. Interestingly, the role of AVP in the regulation of stress-induced HPA activity was not limited to a stressor category (i.e. AVP is involved in both systemic and psychological stressors), and the requirement for AVP was not consistent within a given stressor category. In regards to HPA activity, our results show that changes in plasma corticosterone did not consistently mirror changes in ACTH, except for a few exceptions (Table 4) and that this fact could not be explained by an earlier ACTH peak (as demonstrated by serial blood sampling) or by enhanced adrenal gland sensitivity to ACTH (as confirmed by in vitro studies).

The majority of the stress paradigms tested demonstrated a decreased ACTH response in di/di rats (Table 4). In fact, in over $70 \%$ of the stressors (13 out of 18 ) the neuroendocrine response to stress, i.e. the hypothalamo-pituitary component, was reduced in di/di rats. Interestingly, only in 30\% of the cases where ACTH was reduced (4 out of 13), a decreased corticosterone response was detected as well. In some cases, only one time point was examined, suggesting that perhaps our time point was able to detect the ACTH peak but was premature to detect a difference in corticosterone. However, this explanation cannot explain the lack of difference in corticosterone in the face of different ACTH concentrations in the studies that incorporated serial blood sampling. Enhanced adrenal gland sensitivity to ACTH could have provided a simple explanation; however, a decreased adrenal sensitivity to ACTH in di/di animals was observed and is also supported by previous in vitro (Wiley et al. 1974) and in vivo (Brudieux et al. 1986) studies. Similar dissociations were 

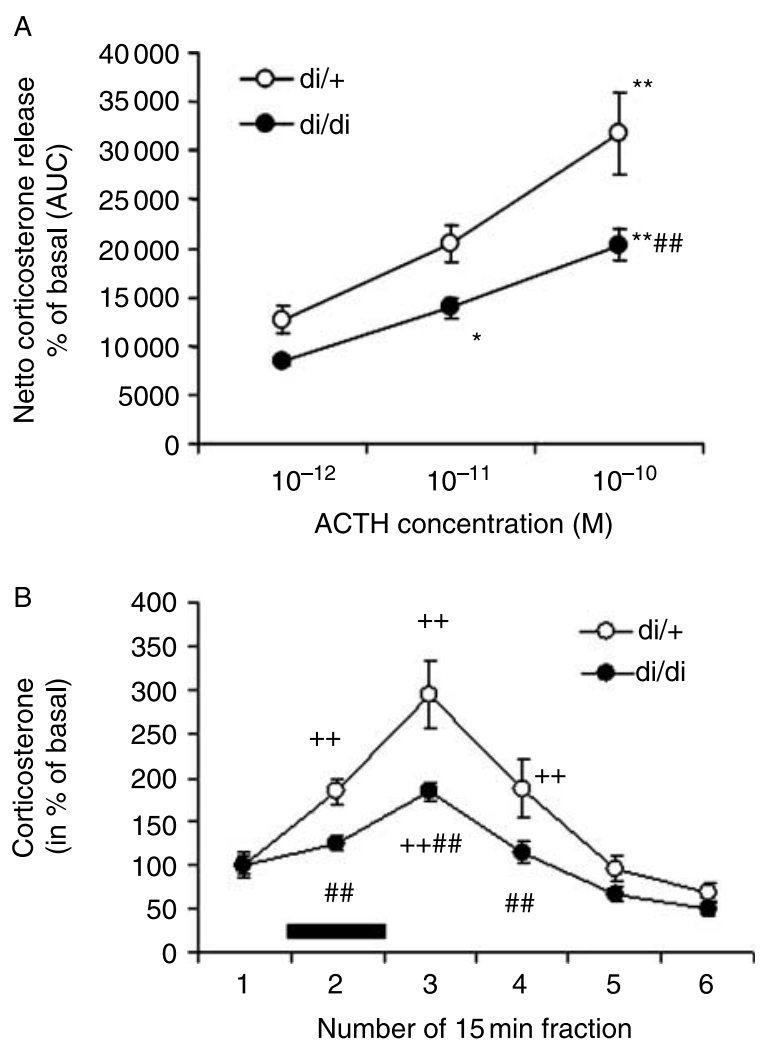

Figure 7 Sensitivity of the adrenal gland to its main secretagogue, ACTH. Corticosterone response to $10^{-12}, 10^{-11}$ and $10^{-10} \mathrm{M}$ ACTH was measured in an in vitro static incubation system. Samples were collected every $15 \mathrm{~min}$. The area under the curve (AUC), i.e. the total amount of secreted corticosterone during 90 min is shown on part A representing a dose-response curve with smaller elevations in di/di rats $(n=10-12)$. The temporal evolution of corticosterone secretion after $10^{-12} \mathrm{M}$ ACTH is illustrated in part $B$. The horizontal bar indicates the duration of ACTH treatment (15 min). ${ }^{++} P<0 \cdot 01$ versus first fraction; ${ }^{*} P<0 \cdot 05,{ }^{* *} P<0 \cdot 01$ versus the effect of $10^{-12} \mathrm{M} \mathrm{ACTH} ;{ }^{\# \#} P<0 \cdot 01$ versus $\mathrm{di} /+$.

found in studies using the $\mathrm{V} 1 \mathrm{~b}$ receptor antagonist (Org) in Sprague-Dawley rats (Spiga et al. 2009) and in the V1b receptor $\mathrm{KO}$ mice (Stewart et al. 2008), demonstrating that phenomenon is not species specific. The fact that the discrepancy between ACTH and corticosterone could not be explained by ACTH sensitivity or missed time points raises the possibility that other peripheral mediators are involved and may be acting directly on the adrenal gland. It supports the theory of paraadenohypophyseal neuroendocrine regulation (Elifanov et al. 1988) and requires further studies. The discrepancy between vasopressinergic ACTH and corticosterone regulation requires further attention in the face that $\mathrm{V} 1 \mathrm{~b}$ antagonists are under development for treatment of stress-related disorders with the assumption that they will decrease the HPA axis hyperactivity.

We observed three types of HPA responses in AVP deficient rats: 1) stressors with decreased ACTH and corticosterone response (for e.g. morphine injection, aggression, restraint), 2) stressors with decreased ACTH response but no change in corticosterone (for e.g. novelty, EPM, forced swim, hypoglycaemia, egg white), 3) stimuli without a change in ACTH or corticosterone (for e.g. social avoidance, footshock, ether inhalation; Table 4). It has been hypothesised that the brain categorises stressors and utilises neural response pathways that vary in accordance with their assigned category (Herman et al. 1996). There are many ways by which stressors have been categorised: 1) intensity (weak or strong), 2) psychological (novelty, social avoidance, EPM), physical (aggression, restraint, footshock, forced swim, immobilisation, ether inhalation; Dayas et al. 2001) or metabolic (hypertonic saline, immune exposure, hypoglycaemia; Carrasco \& Van de Kar 2003), 3) cognitive (restraint) or non-cognitive (infections; Lolait et al. 2007a), 4) systemic (cardiovascular, osmotic and immune challenge) or neurogenic (restraint, immobilisation and electrical footshock; Sawchenko et al. 2000), 5) interoceptive (reflex responses) or exteroceptive (affective and visceromotor responses; for e.g. acute footshock; Sawchenko et al. 2000). Of the abovementioned stressor categories, none were able to fit with it and classify the three types of responses we observed with differential roles for AVP involvement: 1) AVP regulates both ACTH secretion and corticosterone release, 2) AVP also regulates $\mathrm{ACTH}$ secretion but does not affect corticosterone release, 3) no obvious role of AVP in HPA axis regulation. Thus, the role of AVP in HPA regulation during stress is neither limited to nor specified for a known stressor category.

Magnocellular AVP plays an important role in fluid homeostasis and based upon the fact that $A v p$ mRNA in the parvocellular PVN responds rapidly to osmotic stimulus (Lightman \& Young 1988), we expected to observe a massive role of AVP in HPA axis regulation during osmotic stimulus. We were surprised that our results did not confirm this assumption, i.e. that AVP is required for the HPA response to osmotic stimuli. Water deprivation in Brattleboro rats led to a similar conclusion (Popova et al. 2002). It is possible that oxytocin compensates for the loss of AVP in this process as it is also stimulated by osmotic challenges (Schlosser et al. 1994). However, the control procedure (volume load) induced the HPA axis activation was markedly reduced in the absence of AVP. This is consistent with the fact that volume changes (bleeding) increase AVP release (Lewandowska et al. 1992, Lipinska et al. 2004).

Of the stressors tested, there were two stressors i.e. immune challenge and insulin-induced hypoglycaemia, where the contribution of AVP was of a large magnitude. An immune challenge (LPS or egg white) activates the PVN, especially the AVP-containing neurons (Foldes et al. 2000), and the activation is not limited to the parvicellular neurons of the PVN. During the stronger anaphylactic stimulus (egg white), the role of AVP was confirmed in ACTH regulation although there was no effect on corticosterone levels. The weaker stimulus, LPS injection, induced ACTH elevation only in $\mathrm{di} /+$ rats, resembling previous studies using $\mathrm{V} 1 \mathrm{~b}$ receptor $\mathrm{KO}$ mice (Lolait et al. 2007a) and V1b receptor antagonist 
Table 4 Summary of the examined hormone changes in Brattleboro rats. The last three cases are our previously published data. The peak hormone values measured in $\mathrm{di} /+$ animals are presented in columns 4 and 6 . The list of stresses is given in the order appearing in the text. ACTH levels are expressed as $\mathrm{fmol} / \mathrm{ml}$ and corticosterone as $\mathrm{pmol} / \mathrm{ml}$. The method of blood sampling is indicated in column 3 . In case of i.v. blood sampling more time points were examined. The presence of significant changes in di/di animals compared with their heterozygous littermates is indicated in columns 5 and 7 . There are 18 stressors and in 13 cases the ACTH levels were significantly lower in AVP-deficient animals, while we could find impaired corticosterone elevation just in 4 cases

\begin{tabular}{|c|c|c|c|c|c|}
\hline Source & Blood & Max. ACTH & ACTH in di/di & Max. cort. & Cort. in $\mathrm{di} / \mathrm{d}$ \\
\hline Fig. 2 & Decap. & $79 \cdot 3 \pm 16$ & $\downarrow$ & $596 \cdot 6 \pm 102$ & $\mathrm{NO}$ \\
\hline Table 3 & Tail & $110 \cdot 4 \pm 18$ & $\mathrm{NO}$ & $339 \cdot 5 \pm 76$ & $\mathrm{NO}$ \\
\hline Table 3 & Tail & $153 \cdot 4 \pm 18$ & $\downarrow$ & $534 \cdot 7 \pm 36$ & $\mathrm{NO}$ \\
\hline Table 3 & Decap. & $295 \cdot 2 \pm 106$ & $(\downarrow)$ & $962 \cdot 8 \pm 201$ & $\mathrm{NO}$ \\
\hline Table 3 & Decap. & $1027 \cdot 5 \pm 75$ & $\mathrm{NO}$ & $721 \cdot 1 \pm 94$ & $\mathrm{NO}$ \\
\hline Fig. 3 control & i.v. & $146 \cdot 3 \pm 25$ & $\downarrow$ & $954 \cdot 5 \pm 165$ & $\downarrow$ at $15 \mathrm{~min}$ \\
\hline Fig. 3 & i.v. & $443 \cdot 3 \pm 34$ & $\downarrow$ at $60 \mathrm{~min}$ & $977 \cdot 9 \pm 80$ & $\mathrm{NO}$ \\
\hline Fig. 3 & i.v. & $824 \cdot 3 \pm 84$ & $\downarrow$ & $1073 \cdot 8 \pm 91$ & $\mathrm{NO}$ \\
\hline Fig. 3 & i.v. & $360 \cdot 2 \pm 51$ & NO & $979 \cdot 4 \pm 67$ & NO \\
\hline Fig. 3 & i.v. & $575 \cdot 4 \pm 64$ & $\mathrm{NO}$ & $961 \cdot 1 \pm 76$ & $\mathrm{NO}$ \\
\hline Fig. 4 & i.v. & $544 \cdot 4 \pm 55$ & $\downarrow$ & $1162 \cdot 1 \pm 64$ & $\downarrow$ \\
\hline Fig. 4 & i.v. & $464 \cdot 9 \pm 85$ & $\downarrow$ & $918 \cdot 0 \pm 114$ & $\downarrow$ \\
\hline Fig. 5 & i.v. & $887 \cdot 1 \pm 53$ & $\downarrow$ at $60 \mathrm{~min}$ & $1701 \cdot 8 \pm 221$ & $\mathrm{NO}$ \\
\hline Fig. 5 & Decap. & $802 \cdot 9 \pm 45$ & $\downarrow$ & $2622 \cdot 5 \pm 232$ & NO \\
\hline Fig. 5 & i.v. & $602 \cdot 3 \pm 45$ & $\downarrow$ at $5 \mathrm{~min}$ & $1943 \cdot 9 \pm 152$ & $\mathrm{NO}$ \\
\hline Domokos et al. (2008) & i.v. & $276 \cdot 0 \pm 38$ & $\downarrow$ & $1144 \cdot 9 \pm 113$ & $\downarrow$ \\
\hline Zelena et al. (2005) & i.v. & $339 \cdot 7 \pm 48$ & NO & $870 \cdot 7 \pm 77$ & $\mathrm{NO}$ \\
\hline Zelena et al. (2005) & i.v. & $384 \cdot 6 \pm 49$ & $\downarrow$ at $5 \mathrm{~min}$ & $1008 \cdot 2 \pm 82$ & $\mathrm{NO}$ \\
\hline
\end{tabular}

Cort., corticosterone

(Org; Spiga et al. 2009), further confirming the role of AVP during immune stress. The dissociation between ACTH and corticosterone has been observed before (Spiga et al. 2009), although not by all (Lolait et al. 2007a).

During insulin-induced hypoglycaemia a preferential release of AVP over CRH into the hypophysial portal blood was described (Plotsky et al. 1985). The role of AVP was further confirmed in $\mathrm{V} 1 \mathrm{~b}$ receptor $\mathrm{KO}$ mice not only on blood glucose regulation (Fujiwara et al. 2007), but also directly on the HPA axis (Fujiwara et al. 2007, Lolait et al. 2007a). Our results suggest a prominent, although not exclusive, role for AVP in the regulation of ACTH secretion during insulininduced hypoglycaemia. In contrast to results in $\mathrm{V} 1 \mathrm{~b}$ receptor KO mice, Brattleboro animals did not demonstrate a corticosterone change following ACTH diminution.

The in vivo and in vitro experiments demonstrate that the $\mathrm{ACTH}$ response to $\mathrm{CRH}$ is lower in AVP-deficient rats (Buckingham 1981). This observation highlights the prominent role of AVP in ACTH secretion during acute challenges via supporting the effect of CRH (Buckingham \& Leach 1980, Ono et al. 1985, Lightman \& Young 1988). The lack of effect in di/di animals on the CRH-induced cAMP signalling demonstrates that the $\mathrm{CRH}$ signalling cascades remained effective while the ACTH response was dampened, suggesting that our effect was not due to loss of $\mathrm{CRH}$ signalling capacity.

The role of AVP in maintaining the basal hormonal activity of the HPA axis (ACTH and corticosterone secretion) is not supported by our results, consistently with previous reports
(Zelena et al. 2004, 2006a, Domokos et al. 2008) and also human data from diabetes insipidus patients (Itagaki et al. 2001). Moreover, the secretion pattern of the two hormones was also similar between the two genotypes. It was surprising as AVP shows circadian rhythms of synthesis and release within the suprachiasmatic nucleus (Engelmann et al. 1998), so its absence could have disturbed the daily rhythms of HPA axis hormone production as well. However, on the basis of the present results it seems that the lack of AVP in Brattleboro rats does not influence the pattern of the secretion, similar to results in V1b receptor KO mice (Lolait et al. 2007a) and in rats given the V1b receptor antagonist (Spiga et al. 2009).

In resting conditions, Crh mRNA in the PVN was higher in di/di animals (Mlynarik et al. 2007). In the Brattleboro rats, several molecules might serve to compensate for the lack of AVP, thereby reducing the magnitude of our observed effects. The observed Crh mRNA elevation in the PVN might be one of them, although it is worth noting that hypothalamic CRH content, as well as the concentration of CRH in portal blood, has been found to be unchanged (Kjaer et al. 1993). The structurally related other nonapeptide oxytocin, is another possible candidate which can act also on V1b receptors (Schlosser et al. 1994). In our recent study, we have established that although oxytocin mRNA level is elevated in the PVN, the functional replacement remained incomplete (Zelena et al. 2009). The adjacent stress regulatory system, the sympatho-adrenomedullary axis is also functioning at an elevated level in homozygote Brattleboro rats (Kvetnansky et al. 1990). Besides these well-known 
components involved in stress regulation some minor elements may play a prominent role during AVP deficiency. Circulating atrial natriuretic peptide concentration was found to be elevated in di/di animals (Burgess \& Handa 1992) and there is a physiological correlation between hypothalamic histamine and AVP systems (Correa \& Saavedra 1983). The fact that during the perinatal period the lack of AVP completely abolished the maternal separation induced ACTH release (Zelena et al. 2008) suggests that the appearance of a compensatory element in adult Brattleboro rats may hide the importance of AVP in acute HPA axis regulation. However, the results with other tools (immune- or pharmacological blockade), consistent with the results presented in this study support that, in contrast to pups, the role of AVP in HPA axis regulation is not exclusive during adulthood.

For proper interpretation of our results we incorporated additional control groups, as previously discussed (Bohus \& de Wied 1998, Zelena et al. 2003b). To exclude the consequences of the heterozygous state in our di/ + control animals in one experimental series we used Wistar rats as a control group and in another experiment $\mathrm{a}+/+$ line breed out from our Brattleboro colony was used. These studies supported the assumption that one functional allele in di/ + animals are sufficient to allow for full HPA axis activation, as no difference was revealed between $\mathrm{di} /+$ and Wistar or + $/+$ rats even during strong stress exposure, such as ulcerogenic stimulus. Peripheral AVP deficiency leads to diabetes insipidus and might result in a chronic stress state with reduced stress reactivity to further stimuli (Aguilera 1994). The unchanged somatic parameters (Table 2) as well as the retained corticosterone elevations did not support this assumption. The influence of peripheral AVP deficiency was excluded by using DDAVP containing osmotic minipumps (Zelena et al. 2006b) thereby demonstrating that the changes observed in the present study were due to the loss of central vasopressinergic regulation.

Immune (egg white, LPS) and metabolic (hypoglycaemia) challenges are two prominent areas with important vasopressinergic ACTH secretion regulation. Although glucocorticoids are the main end-product of the HPA axis, changes in ACTH were not always accompanied by changes in corticosterone, thereby raising the question of the importance of ACTH secretion. In addition to its well-established role in glucocorticoid release, ACTH has a trophic effect in the mammalian adrenal cortex, allowing the expression of genes encoding steroidogenic enzymes (Saez et al. 1989). In addition to the adrenal cortex (Voisey et al. 2003), ACTH receptors are also found on adipocytes (Boston \& Cone 1996), skin cells (Kapas et al. 1998) and sympathetic ganglia (Nankova et al. 1996). Furthermore, it has been proposed that ACTH can also participate in immunmodulation (Weigent \& Blalock 1987).

As a conclusion, our results support the important role of AVP in the regulation of ACTH secretion during acute stress. The requirement for AVP in acute stress regulation of HPA activity was observed in a variety of stressors and was not specified for nor limited to a known stressor category.

\section{Declaration of interest}

The authors declare that there is no conflict of interest that could be perceived as prejudicing the impartiality of the research reported.

\section{Funding}

This work was supported by OTKA grants to D Z (48783, 67249, NN71629).

\section{Author contribution statement}

Planning the experiments: D Z, L F; conducting the experiments: D Z, Á D, $\mathrm{S} \mathrm{K} \mathrm{J}, \mathrm{L} \mathrm{F}$; analysing the data: $\mathrm{D} \mathrm{Z}, \mathrm{A} \mathrm{D}, \mathrm{S} \mathrm{K} \mathrm{J}, \mathrm{L} \mathrm{F}$; preparing the manuscript D Z, S K J, R J, L F.

\section{Acknowledgements}

We would like to thank Ms K Varga for hormone measurements.

\section{References}

Aguilera G 1994 Regulation of pituitary ACTH secretion during chronic stress. Frontiers in Neuroendocrinology 15 321-350.

Antoni FA \& Dayanithi G 1990 Evidence for distinct glucocorticoid and guanine $3^{\prime}, 5^{\prime}$-monophosphate-effected inhibition of stimulated adrenocorticotropin release in vitro. Endocrinology 126 1355-1360.

Barna I, Bálint E, Baranyi J, Bakos N, Makara GB \& Haller J 2003 Gender-specific effect of maternal deprivation on anxiety and corticotropin-releasing hormone mRNA expression in rats. Brain Research Bulletin 62 85-91.

Bohus B \& de Wied D 1998 The vasopressin deficient Brattleboro rats: a natural knockout model used in the search for CNS effects of vasopressin. Progress in Brain Research 119 555-573.

Boston BA \& Cone RD 1996 Characterization of melanocortin receptor subtype expression in murine adipose tissues and in the 3T3-L1 cell line. Endocrinology 137 2043-2050.

Brooker G, Harper JF, Terasaki WL \& Moylan RD 1979 Radioimmunoassay of cyclic AMP and cyclic GMP. Advances in Cyclic Nucleotide Research $101-33$.

Brudieux R, Krifi MN \& Laulin JP 1986 Release of aldosterone and corticosterone from the adrenal cortex of the Brattleboro rat in response to administration of ACTH. Journal of Endocrinology 111 375-381.

Buckingham JC 1981 The influence of vasopressin on hypothalamic corticotrophin releasing activity in rats with inherited diabetes insipidus. Journal of Physiology 312 9-16.

Buckingham JC \& Leach JH 1980 Hypothalamo-pituitary-adrenocortical function in rats with inherited diabetes insipidus. Journal of Physiology 305 397-404.

Burgess WJ \& Balment RJ 1992 Plasma atrial natriuretic peptide in vasopressin deficiency: the effects of acute water deprivation in rats. Journal of Endocrinology 135 431-438.

Burgess LH \& Handa RJ 1992 Chronic estrogen-induced alterations in adrenocorticotropin and corticosterone secretion, and glucocorticoid receptor-mediated functions in female rats. Endocrinology 131 1261-1269. 
Carrasco GA \& Van de Kar LD 2003 Neuroendocrine pharmacology of stress. European Journal of Pharmacology 463 235-272.

Correa FM \& Saavedra JM 1983 High histamine levels in specific hypothalamic nuclei of Brattleboro rats lacking vasopressin. Brain Research 276 247-252.

Dallman M 1993 Stress update adaptation of the hypothalamic-pituitaryadrenal axis to chronic stress. Trends in Endocrinology and Metabolism $\mathbf{4}$ $62-69$.

Dayas CV, Buller KM, Crane JW, Xu Y \& Day TA 2001 Stressor categorization: acute physical and psychological stressors elicit distinctive recruitment patterns in the amygdala and in medullary noradrenergic cell groups. European Journal of Neuroscience 14 1143-1152.

Domokos A, Mergl Z, Barna I, Makara GB \& Zelena D 2008 Congenital vasopressin deficiency and acute and chronic opiate effects on hypothalamo-pituitary-adrenal axis activity in Brattleboro rats. Journal of Endocrinology 196 113-121.

Eckland DJ, Todd K \& Lightman SL 1988 Immunoreactive vasopressin and oxytocin in hypothalamo-hypophysial portal blood of the Brattleboro and Long-Evans rat: effect of adrenalectomy and dexamethasone. Journal of Endocrinology 117 27-34.

Elifanov AV, Polenov AL, Belen'kir MA \& Kuzik VV 1988 Morphofunctional research on the interrenal gland of the frog Rana temporaria following arginine vasotocin administration. Zhurnal Evoliutsionnoi Biokhimii i Fiziologii 24 740-744.

Engelmann M, Ebner K, Landgraf R \& Wotjak CT 1998 Swim stress triggers the release of vasopressin within the suprachiasmatic nucleus of male rats. Brain Research 792 343-347.

Filaretova LP, Filaretov AA \& Makara GB 1998 Corticosterone increase inhibits stress-induced gastric erosions in rats. American Journal of Physiology 274 G1024-G1030.

Foldes A, Nemethy Z, Szalay O \& Kovacs KJ 2000 Anaphylactoid reactions activate hypothalamo-pituitary-adrenocortical axis: comparison with endotoxic reactions. Brain Research Bulletin 52 573-579.

Fujiwara Y, Hiroyama M, Sanbe A, Aoyagi T, Birumachi J, Yamauchi J, Tsujimoto G \& Tanoue A 2007 Insulin hypersensitivity in mice lacking the V1b vasopressin receptor. Journal of Physiology 584 235-244.

Haller J, Leveleki C, Baranyi J, Mikics E \& Bakos N 2003 Stress, social avoidance and anxiolytics: a potential model of stress-induced anxiety. Behavioural Pharmacology 14 439-446.

Herman JP, Prewitt CM \& Cullinan WE 1996 Neuronal circuit regulation of the hypothalamo-pituitary-adrenocortical stress axis. Critical Reviews in Neurobiology 10 371-394.

Honda K, Fukuda S, Ishikawa SE, Kuzuya T \& Saito T 1994 Role of endogenous vasopressin in development of gastric ulcer induced by restraint and water immersion. American Journal of Physiology 266 R1448-R1453.

Itagaki E, Ozawa S, Yamaguchi S, Ushikawa K, Tashiro T, Katahira H, Takizawa M, Yoshimoto K, Murakawa S \& Ishida H 2001 Increases in plasma ACTH and cortisol after hypertonic saline infusion in patients with central diabetes insipidus. Journal of Clinical Endocrinology and Metabolism 86 5749-5754.

Kapas S, Hagi-Pavli E, Brown DW, Chhajlani V \& Farthing PM 1998 Direct effects of corticotrophin on oral keratinocyte cell proliferation. European Journal of Biochemistry 256 75-79.

Kjaer A, Knigge U, Bach FW \& Warberg J 1993 Impaired histamine- and stress-induced secretion of ACTH and beta-endorphin in vasopressindeficient Brattleboro rats. Neuroendocrinology 57 1035-1041.

Kvetnansky R \& Mikulaj L 1970 Adrenal and urinary catecholamines in rats during adaptation to repeated immobilization stress. Endocrinology 87 738-743.

Kvetnansky R, Jezova D, Oprsalova Z, Foldes O, Michajlovskij N, Dobrakovova M, Lichardus B \& Makara GB 1990 Regulation of the sympathetic nervous system by circulating vasopressin. Advances in Experimental Medicine and Biology 274 113-134.

Lewandowska A, Glowacka A \& Guzek JW 1992 The vasopressin and oxytocin neurohypophysial content as influenced by bleeding or dehydration: effect of cholecystokinin octapeptide. Journal of Physiology and Pharmacology 43 153-163.
Lightman SL \& Young WS III 1988 Corticotrophin-releasing factor, vasopressin and pro-opiomelanocortin mRNA responses to stress and opiates in the rat. Journal of Physiology 403 511-523.

Lightman SL, Windle RJ, Ma XM, Harbuz MS, Shanks NM, Julian MD, Wood SA, Kershaw YM \& Ingram CD 2002 Hypothalamic-pituitaryadrenal function. Archives of Physiology and Biochemistry 110 90-93.

Lipinska S, Forys S \& Lipinska J 2004 The post-haemorrhagic vasopressin release into the blood. Journal of Physiology and Pharmacology 55 73-83.

Lolait SJ, Markwick AJ, McNally M, Abraham J, Smith AI \& Funder JW 1986 Anterior pituitary cells from Brattleboro (di/di), Long-Evans and Sprague-Dawley rats contain immunoreactive arginine vasopressin. Neuroendocrinology 43 577-583.

Lolait SJ, Stewart LQ, Jessop DS, Young WS III \& O'Carroll AM 2007a The hypothalamic-pituitary-adrenal axis response to stress in mice lacking functional vasopressin V1b receptors. Endocrinology 148 849-856.

Lolait SJ, Stewart LQ, Roper JA, Harrison G, Jessop DS, Young WS III \& O'Carroll AM 2007b Attenuated stress response to acute lipopolysaccharide challenge and ethanol administration in vasopressin $\mathrm{V} 1 \mathrm{~b}$ receptor knockout mice. Journal of Neuroendocrinology 19 543-551.

Ma XM \& Aguilera G 1999 Transcriptional responses of the vasopressin and corticotropin-releasing hormone genes to acute and repeated intraperitoneal hypertonic saline injection in rats. Brain Research. Molecular Brain Research 68 129-140.

Ma XM \& Lightman SL 1998 The arginine vasopressin and corticotrophinreleasing hormone gene transcription responses to varied frequencies of repeated stress in rats. Journal of Physiology 510 605-614.

Mikics E, Barsy B \& Haller J 2007 The effect glucocorticoids on aggressiveness in established colonies of rats. Psychoneuroendocrinology 32 160-170.

Mlynarik M, Zelena D, Bagdy G, Makara GB \& Jezova D 2007 Signs of attenuated depression-like behavior in vasopressin deficient Brattleboro rats. Hormones and Behavior 51 395-405.

Nankova B, Kvetnansky R, Hiremagalur B, Sabban B, Rusnak M \& Sabban EL 1996 Immobilization stress elevates gene expression for catecholamine biosynthetic enzymes and some neuropeptides in rat sympathetic ganglia: effects of adrenocorticotropin and glucocorticoids. Endocrinology 137 $5597-5604$.

Ono N, Bedran de Castro J, Khorram O \& McCann SM 1985 Role of arginine vasopressin in control of ACTH and LH release during stress. Life Sciences 36 1779-1786.

Plotsky PM, Bruhn TO \& Otto S 1985 Central modulation of immunoreactive arginine vasopressin and oxytocin secretion into the hypophysial-portal circulation by corticotropin-releasing factor. Endocrinology 116 1669-1671.

Popova NK, Naumenko KS, Maslova LN, Amstislavskaya TG, Melidi NN, Bulygina VV \& Ivanova LN 2002 Hypothalamic tryptophan hydroxylase and the hypothalamic-pituitary-adrenocortical response to water deprivation and hydration in vasopressin-deficient and normal rats. Pflugers Archiv 444 372-377.

Porsolt RD, Anton G, Blavet N \& Jalfre M 1978 Behavioural despair in rats: a new model sensitive to antidepressant treatments. European Journal of Pharmacology 47 379-391.

Ramos AT, Troncone LR \& Tufik S 2006 Suppression of adrenocorticotrophic hormone secretion by simultaneous antagonism of vasopressin $1 \mathrm{~b}$ and CRH-1 receptors on three different stress models. Neuroendocrinology 84 309-316.

Saez JM, Begeot M \& Durand P 1989 ACTH receptors. Annales d'Endocrinologie 50 409-417.

Sawchenko PE, Li HY \& Ericsson A 2000 Circuits and mechanisms governing hypothalamic responses to stress: a tale of two paradigms. Progress in Brain Research 122 61-78.

Schlosser SF, Almeida OF, Patchev VK, Yassouridis A \& Elands J 1994 Oxytocin-stimulated release of adrenocorticotropin from the rat pituitary is mediated by arginine vasopressin receptors of the V1b type. Endocrinology 135 2058-2063.

Scott LV \& Dinan TG 2002 Vasopressin as a target for antidepressant development: an assessment of the available evidence. Journal of Affective Disorders 72 113-124. 
Selye H 1937 The significance of the adrenals for adaptation. Science $\mathbf{8 5}$ 247-248.

Serradeil-Le Gal C, Wagnon J, Simiand J, Griebel G, Lacour C, Guillon G, Barberis C, Brossard G, Soubrie P, Nisato D et al. 2002 Characterization of (2S,4R)-1-[5-chloro-1-[(2,4-dimethoxyphenyl)sulfonyl]-3-(2-methoxyphenyl) -2-oxo-2,3-dihydro-1H-indol-3-yl]-4-hydroxy- N,N-dimethyl-2pyrrolidine carboxamide (SSR 149415), a selective and orally active vasopressin V1b receptor antagonist. Journal of Pharmacology and Experimental Therapeutics 300 1122-1130.

Spiga F, Harrison LR, Wood S, Knight DM, MacSweeney CP, Thomson F, Craighead M \& Lightman SL 2009 Blockade of the V(1b) receptor reduces ACTH, but not corticosterone secretion induced by stress without affecting basal hypothalamic-pituitary-adrenal axis activity. Journal of Endocrinology $200273-283$

Stachura ME, Tyler JM \& Farmer PK 1985 Human pancreatic growth hormone-releasing factor-44 differentially stimulates release of stored and newly synthesized rat growth hormone in vitro. Endocrinology 116 698-706.

Stewart LQ, Roper JA, Young WS III, O'Carroll AM \& Lolait SJ 2008 Pituitary-adrenal response to acute and repeated mild restraint, forced swim and change in environment stress in arginine vasopressin receptor $1 \mathrm{~b}$ knockout mice. Journal of Neuroendocrinology 20 597-605.

Tanoue A, Ito S, Honda K, Oshikawa S, Kitagawa Y, Koshimizu TA, Mori T \& Tsujimoto G 2004 The vasopressin V1b receptor critically regulates hypothalamic-pituitary-adrenal axis activity under both stress and resting conditions. Journal of Clinical Investigation 113 302-309.

Tilders FJ, Berkenbosch F, Vermes I, Linton EA \& Smelik PG 1985 Role of epinephrine and vasopressin in the control of the pituitary-adrenal response to stress. Federation Proceedings 44 155-160.

Valtin H \& Schroeder HA 1964 Familial hypothalamic diabetes insipidus in rats (Brattleboro strain). American Journal of Physiology 206 425-430.

Voisey J, Carroll L \& van Daal A 2003 Melanocortins and their receptors and antagonists. Current Drug Targets 4 586-597.

Weigent DA \& Blalock JE 1987 Interactions between the neuroendocrine and immune systems: common hormones and receptors. Immunological Reviews 100 79-108.

Wiley MK, Pearlmutter AF \& Miller RE 1974 Decreased adrenal sensitivity to ACTH in the vasopressin-deficient (Brattleboro) rat. Neuroendocrinology 14 257-270.

Zelena D, Haller J, Halasz J \& Makara GB 1999a Social stress of variable intensity: physiological and behavioral consequences. Brain Research Bulletin 48 297-302.

Zelena D, Kiem DT, Barna I \& Makara GB 1999 b Alpha 2-adrenoreceptor subtypes regulate ACTH and beta-endorphin secretions during stress in the rat. Psychoneuroendocrinology 24 333-343.
Zelena D, Makara GB \& Jezova D 1999c Simultaneous blockade of two glutamate receptor subtypes (NMDA and AMPA) results in stressor-specific inhibition of prolactin and corticotropin release. Neuroendocrinology 69 316-323.

Zelena D, Mergl Z, Foldes A, Kovacs KJ, Toth Z \& Makara GB $2003 a$ Role of hypothalamic inputs in maintaining pituitary-adrenal responsiveness in repeated restraint. American Journal of Physiology. Endocrinology and Metabolism 285 E1110-E1117.

Zelena D, Mergl Z \& Makara GB 2003b Maternal genotype influences stress reactivity of vasopressin-deficient brattleboro rats. Journal of Neuroendocrinology 15 1105-1110.

Zelena D, Földes A, Mergl Z, Barna I, Kovács KJ \& Makara GB 2004 Effects of repeated restraint stress on hypothalamo-pituitary-adrenocortical function in vasopressin deficient Brattleboro rats. Brain Research Bulletin 63 521-530.

Zelena D, Mergl Z \& Makara GB 2005 Glutamate agonists activate the hypothalamic-pituitary-adrenal axis through hypothalamic paraventricular nucleus but not through vasopressinerg neurons. Brain Research 1031 185-193.

Zelena D, Filaretova L, Mergl Z, Barna I, Toth ZE \& Makara GB $2006 a$ Hypothalamic paraventricular nucleus, but not vasopressin, participates in chronic hyperactivity of the HPA axis in diabetic rats. American Journal of Physiology. Endocrinology and Metabolism 290 E243-E250.

Zelena D, Mergl Z \& Makara GB $2006 b$ The role of vasopressin in diabetes mellitus-induced hypothalamo-pituitary-adrenal axis activation: studies in Brattleboro rats. Brain Research Bulletin 69 48-56.

Zelena D, Domokos A, Mergl Z \& Makara GB 2007 The role of vasopressin in chronic stress-induced hypothalamo-pituitary-adrenal axis hyperactivity: studies on brattleboro rats with repeated restraint. In Neuropeptide Research Trends, pp 189-212. Ed. BA Levine. Hauppauge, NY: Nova Publishers.

Zelena D, Domokos A, Barna I, Mergl Z, Haller J \& Makara GB 2008 Control of the hypothalamo-pituitary-adrenal axis in the neonatal period: adrenocorticotropin and corticosterone stress responses dissociate in vasopressin-deficient Brattleboro rats. Endocrinology 149 2576-2583.

Zelena D, Langnaese K, Domokos A, Pinter O, Landgraf R, Makara GB \& Engelmann M 2009 Vasopressin administration into the PVN normalizes plasma oxytocin and corticosterone levels in Brattleboro rats. Endocrinology 150 2791-2798.

Received in final form 8 May 2009

Accepted 19 May 2009

Made available online as an Accepted Preprint

19 May 2009 